\title{
The relevant information about the severe acute respiratory syndrome coronavirus 2 (SARS-CoV-2) using the five-question approach (when, where, what, why, and how) and its impact on the environment
}

\author{
Faizah A. AIMalki ${ }^{1}$ Salim Albukhaty ${ }^{2} \cdot$ Amal A. Alyamani $^{3} \cdot$ Moayad N. Khalaf $^{4} \cdot$ Sabu Thomas $^{5}$
}

Received: 10 August 2021 / Accepted: 21 January 2022

(c) The Author(s), under exclusive licence to Springer-Verlag GmbH Germany, part of Springer Nature 2022

\begin{abstract}
Severe acute respiratory syndrome coronavirus 2 (SARS-CoV-2) is regarded as a threat because it spreads quickly across the world without requiring a passport or establishing an identity. This tiny virus has wreaked havoc on people's lives, killed people, and created psychological problems all over the world. The viral spike protein (S) significantly contributes to host cell entry, and mutations associated with it, particularly in the receptor-binding protein (RBD), either facilitate the escape of virus from neutralizing antibodies or enhance its transmission by increasing the affinity for cell entry receptor, angiotensin-converting enzyme 2 (ACE2). The initial variants identified in Brazil, South Africa, and the UK have spread to various countries. On the other hand, new variants are being detected in India and the USA. The viral genome and proteome were applied for molecular detection techniques, and nanotechnology particles and materials were utilized in protection and prevention strategies. Consequently, the SARS-CoV-2 pandemic has resulted in extraordinary scientific community efforts to develop detection methods, diagnosis tools, and effective antiviral drugs and vaccines, where prevailing academic, governmental, and industrial institutions and organizations continue to engage themselves in large-scale screening of existing drugs, both in vitro and in vivo. In addition, COVID-19 pointed on the possible solutions for the environmental pollution globe problem. Therefore, this review aims to address SARS-CoV-2, its transmission, where it can be found, why it is severe in some people, how it can be stopped, its diagnosis and detection techniques, and its relationship with the environment.
\end{abstract}

Keywords COVID-19 $\cdot$ SARS-CoV-2 variants $\cdot$ SARS-CoV-2 genome and protein $\cdot$ SARS-CoV-2 vaccines $\cdot$ SARS-CoV-2 diagnosis $\cdot$ SARS-CoV-2 and the environment

\section{Introduction}

Responsible Editor: Lotfi Aleya

Faizah A. AlMalki

fa.ahmad@tu.edu.sa

1 Department of Biology, College of Science, Taif University, P.O. Box 11099, Taif 21944, Kingdom of Saudi Arabia

2 Deptartment of Chemistry, College of Science, University of Misan, Maysan 62001, Iraq

3 Department of Biotechnology, College of Science, Taif University, P.O. Box 11099, Taif 21944, Kingdom of Saudi Arabia

4 Deptartment of Chemistry, College of Science, University of Basrah, Basrah, Iraq

5 Centre for Nanoscience and Nanotechnology, Mahatma Gandhi University, Kottayam, Kerala 686 560, India
Coronaviruses $(\mathrm{CoVs})$ belong to the family Coronaviridae and are grouped into four genera, including alpha, beta, gamma, and delta (van Regenmortel et al. 2000; Adams et al. 2016). Viruses belonging to the alpha and beta genera infect mammals, including humans, while birds are infected by those belonging to gamma and delta genera (Yin and Wunderink 2018; Tang et al. 2015). Coronaviruses are approximated to have a $60-100-\mathrm{nm}$, diameter, and their genetic material is enveloped in a protein coat known as the capsid, just like other viruses. In the last two decades, reports indicate three novel coronavirus transmissions to humans, leading to severe acute respiratory syndrome (SARS) disease. SARS-CoV was the first outbreak reported in Guangdong, China, in November 2002 (Zhong et al. 2003). The second 
outbreak was due to the Middle East respiratory syndrome coronavirus (MERS-CoV) and occurred in Saudi Arabia in 2012 (Zaki et al. 2012). The world is currently experiencing the novel coronavirus (2019-nCoV), which was initially reported in China at the end of 2019 (Wang et al. 2020a, b, c). These three coronaviruses are beta-coronaviruses, but SARS-CoV and 2019-nCoV belong to the Sarbecovirus subgenus while MERS-CoV belongs to the Merbecovirus (Wu et al. 2020a). This review takes the five-question approach (when, where, what, why, and how) for the pertinent information about the novel 2019-nCoV that has recently emerged, as well as potential treatment and diagnosis strategies. In addition, the impact of the environmental pollution on the viral transmission and the viral negative and/or positive effects on the environmental conditions were discussed.

\section{When did the 2019-nCoV appear?}

The health authorities in China became aware, in December 2019, that there was a substantial cluster of pneumonia cases in the city of Wuhan in Hubei province; the source of the cases was not clear, and the infection was swiftly spreading (Eurosurveillance editorial team 2020). Patient samples were collected, and analysis was carried out to discover the reason for the infections. China was the first country to identify the disease, named severe acute respiratory syndrome coronavirus 2 (SARS-CoV-2) by the International Committee on Taxonomy of Viruses (ICTV) (Gorbalenya et al. 2020). Individuals who contracted SARS-CoV-2 suffered a respiratory disease that WHO named coronavirus disease 2019 (COVID-19) (Sohrabi et al. 2020; Paraskevis et al. 2020; Wu et al. 2020a, b, c). The disease may display symptoms ranging from those found in normal cases of flu to breathing difficulties and pneumonia that, in the most serious cases, can be fatal. Standard symptoms for COVID-19 are a dry cough, sore throat, tight chest, fever, headaches, and dyspnea (Guo et al. 2020). Sufferers may lose the ability to taste and smell, and some have suffered gastrointestinal infections (Guan et al. 2020). Recent research in France and Italy has shown that SARS-CoV-2 reached Europe at an early stage. The samples taken between November 2019 and January 2020 (France) and September 2019 and March 2020 (Italy) have been found to carry anti-SARS-CoV-2 antibodies, IgG and/or IgM (Apolone et al. 2020; Carrat et al. 2021). Sallard et al. (2021) have investigated potential sources of SARS-CoV-2, raising important questions as to the origins of the virus being either naturally occurring or man-made. At the start of 2021, WHO sent a cohort of international scientists to undertake investigations into the origins of the virus. They commenced working in Wuhan, reportedly the breeding ground for the global pandemic. The WHO team reported that the virus was most likely of animal origin, which was then passed on to humans, disagreeing with suggestions that it had escaped from a virology laboratory in Wuhan (WHO 2020a, b). Nevertheless, there is still considerable dispute as to the source of the virus; it could have been a Wuhan laboratory accident or animal exposure, but it seems unlikely that an intentional release occurred.

\section{Where does SARS-CoV-2 spread?}

When a new pathogenic appears, discovering the source is important. Where possible, the source must be identified and isolated to prevent additional variants of the pathogen from crossing into humans. Finding the source is also helpful in understanding the dynamics of the virus, which can help shape public health responses and can also be of assistance when developing therapies and vaccines. There is considerable similarity between all published genetic sequences for the SARS-CoV-2 virus in humans, which suggests that the outbreak began with the virus moving into the human population at one point, in time that first reports appeared. However, researchers do not currently know the zoonotic source of the virus. As previously mentioned, SARS-CoV-2 was initially identified in Wuhan, China, at the end of 2019, and swiftly spread to other nations through international travel networks. Published genetic sequences appear to show that the virus jumped from animals to humans in the last few months of 2019 (Islam et al. 2020). At the time of writing (August $8,2021)$, most, if not all, countries have experienced the virus, with above 200 million cases confirmed with an approximate $2 \%$ mortality (https://covid19.who.int/). The highest number of confirmed cases has been in the USA (more than 36 million with $1.8 \%$ mortality). In terms of case numbers with considering the fast increasing in these numbers daily, India is second, Brazil third, and Russia fourth, as shown in Table 1.

Table 1 Summarizes information about the most infected countries with SARS-CoV-2. (https://sehhty.com, accessed August 8, 2021)

\begin{tabular}{lrrll}
\hline Country & No. of cases & No. of survivals & No. of deaths & Death \% \\
\hline USA & $36,518,948$ & $29,851,803$ & 632,987 & 1.7 \\
India & $31,934,455$ & $31,099,771$ & 427,892 & 1.3 \\
Brazil & $20,151,779$ & $18,894,631$ & 563,082 & 2.8 \\
Russia & $6,447,750$ & $5,755,507$ & 164,881 & 2.6 \\
\hline
\end{tabular}




\section{What is SARS-Cov-2?}

The new coronavirus was confirmed as a human coronavirus by sequencing and analyzing its genome (Fig. 1). The new virus shares similarity with a bat RaTG13 virus (96\%), as well as with SARS-CoV (79\%) (Zhou et al. 2020).

\section{The viral genome}

Observations have revealed that SARS-CoV-2 has a positive-sense single-stranded RNA molecule approximated to be around $30 \mathrm{~Kb}$. This RNA encodes a wide range of viral proteins and consists of the 5'-leader-UTR, 3'-UTR poly-A tail, structural proteins replicase, and genes encoding accessory proteins located in the $3^{\prime}$ end. Also, these observations highlighted the genome of coronaviruses to be the largest known RNA genome (Hilgenfeld and Peiris 2013). Intriguingly, a study by Nelson et al. (2020) noted a group of overlapping genes (OLGs) and informed the presence of a novel-overlapping gene in the SARS-CoV-2 genome known as ORF3d that has not been recognized or reported before (Fig. 2a). The OLGs are familiar in the viruses' genome and are associated with pandemics, but have not gained much

Fig. 1 Diagram showing the general structure of SARSCoV-2 with the viral genome (RNA) and the primary structural proteins, S, M, E, and N
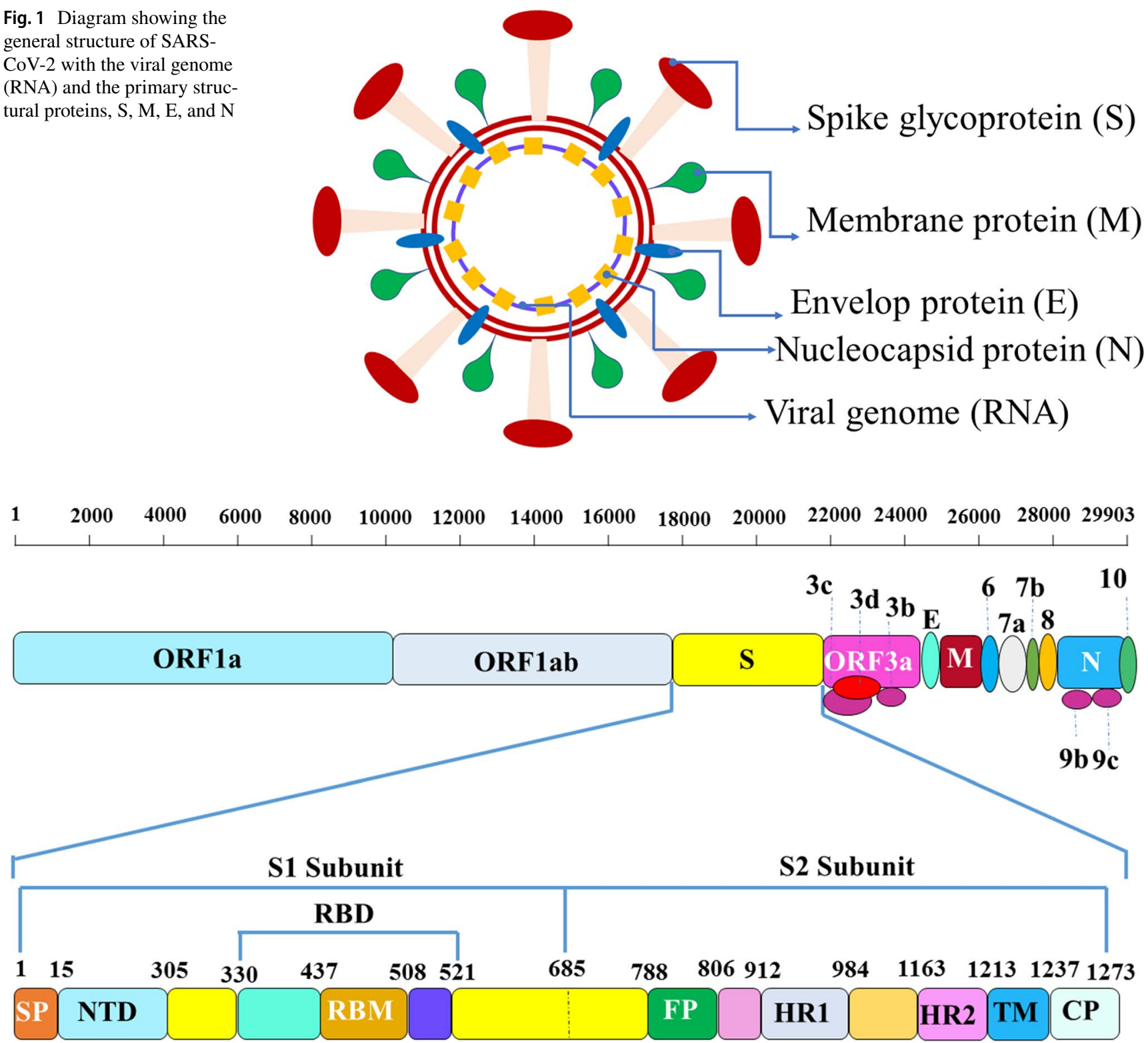

Fig. 2 Schematic illustrating (a) severe acute respiratory syndrome coronavirus 2 (SARS-CoV-2) genome sequence, (b) spike (S) glycoprotein structure. SP: signal peptide; NTD: N-terminal domain; RBD: receptor binding domain; FP: fusion protein; HR1 and HR2: heptad repeat regions 1 and 2; TM: transmembrane; CP: cytoplasmic tail 
attention from researchers. This ORF3d was suggested to have 57 amino acids organized in $\alpha$-helices joined by loops. In addition, Nelson et al. (2020) noted the presence of some conserved OLGs in coronaviruses, including ORF3c, ORF3b, ORF9b, and ORF9c (Fig. 2a). Another study by Manfredonia et al. (2020) utilized SHAPE and DMA mutational profiling (Map) to explore the RNA structure of the new SARS-CoV-2 and observed a group of RNA structural elements. This study also generated the 3D models for the RNA structure segments, which offer a platform for designing and developing small molecule drugs targeting the viral genome (Manfredonia et al. 2020).

\section{Deletions in the SARS-CoV-2 genome}

Previous studies noted that the deletion of 29 nucleotides ( $~ 9$ amino acids) in human SARS-CoV at the open reading frame 8 (ORF8) reduced the replication potential of the virus by up to 23-fold (Lau et al. 2005; Consortium 2004; Muth et al. 2018). This region is believed to encode an accessory protein essential to replicating the virus and the person-toperson transmission mechanisms (Oostra et al. 2007; Lau et al. 2015). An extensive truncated sequence with 382 nucleotides was observed in the SARS-CoV-2 genome in the ORF8 region which occupied the transcription-regulation area. According to the analysis of samples gathered from eight hospitals in Singapore (between January and February 2020), this extensive truncated sequence deletion resulted in an attenuated SARS-CoV-2 infection phenotype ( $\mathrm{Su}$ and $\mathrm{Wu}$ 2020). This led researchers to hypothesis that this type of deletion occurred after the virus surfaced to support its survival in humans (Tang et al. 2015). Another deletion noted early in the SARS-CoV-2 genome was reported in Tempe, Arizona (USA). The deleted region is composed of about 81 nucleotides (27 amino acids), and its deletion affected the ORF7a deemed to encode an accessory protein (Holland et al. 2020). Nonetheless, the impact of this deletion on the gene function remains unclear.

\section{The viral proteins}

It has been noted that the SARS-CoV-2 genome contains 14 ORFs that encode about 27 different proteins, as indicated by Fig. 2a. Viral-associated proteins can be grouped into three categories: structural, nonstructural, and accessory proteins (Wu et al. 2020a, b, c; Cui et al. 2019).

\section{Structural proteins}

The coronavirus structural proteins include the spike (S) glycoprotein, the small envelope (E), the matrix (M), and the nucleocapsid $(\mathrm{N})$ encapsulating the viral genome and all of which are essential in viral replication (Fig. 2a) (Huang et al. 2004). S-Glycoprotein is considered the largest viral protein consisting of more than 1200 amino acids $(150 \mathrm{kDa})$, and each monomer is believed to have numerous $\mathrm{N}$-glycosylation sites. This protein is found on the surface of the virus and is a class 1 viral fusion protein. In addition, $\mathrm{S}$-glycoprotein is categorized into two functional domains, $\mathrm{S} 1$ and S2, as indicated by Fig. 2b; these two categories are further grouped into two subdomains, where the S1 domain is believed to have a C-domain holding the RBD and N-terminal domain (NTD). In contrast, the S2 domain contains two heptad repeats (HR) associated with membrane fusion function (Fig. 2b). The S-glycoprotein acts as the mediator of the interactions between the viral and the host cells from one side and between infected and uninfected cells in the same host on the other side. Cell-to-cell infection is achieved through cell-cell fusion, facilitating the direct spread between the cells evading the immune system $(\mathrm{Du}$ et al. 2009). The central target receptor on surfaces of human cells is the angiotensin-converting enzyme 2 (ACE2). This homotrimeric S-glycoprotein is used by coronaviruses to bind, making the RBD essential in interactions between the viruses and host cells (Li et al. 2003; Wan et al. 2020).

\section{RBD structure in SARS-CoV-2, SARS-CoV, and MERS-CoV}

The S-glycoprotein and RBD in coronaviruses have attracted the attention of researchers due to their role in vaccine design and drug development. All the three crystal structures of the RBD associated with SARS-CoV-2, SARS-CoV, and MERS-CoV have been determined and preserved in the protein data bank (PDB) (Lan et al. 2020; Li et al. 2005; Chen et al. 2013). Studies indicate that the three coronaviruses RBD protein is organized in the same form involving a core structure consisting of five antiparallel $\beta$-sheets, some short $\alpha$-helices, and an accessory subdomain [Fig. 3a, b, c (3D structures); d, e, f; (2D)] showing the accessory subdomain consists of loops with short two antiparallel $\beta$-strands in SARS-CoV and six in SARS-CoV-2. In addition, studies highlighted that all three RBD structures differ in the accessory subdomain. However, SARS-CoV-2 and SARS-CoV share more similarities in this accessory subdomain compared to MERS-CoV.

High similarity, indicated by an RMSD of $0.53 \AA \mathrm{C} \alpha$ atoms (superposition), was noted between RBDs of SARSCoV and SARS-CoV-2 (Fig. 4a) while the superimposed RBDs of MERS-CoV and SARS-CoV-2 showed more variations by an RMSD of $3.27 \AA$ for backbone atoms (Fig. 4b).

Similar results can be obtained with the superimposition of the three RBDs together, as indicated in Fig. 4c. The RBDs from the three coronaviruses (SARS-CoV-2, SARS-CoV, and MERS-CoV) contain eight cysteine 
Fig. 3 Illustrations of the structure of RBD in some coronaviruses. Details of three-dimensional crystal structures of (a) MERS-CoV ( $\alpha$-helices colored violet, $\beta$-sheets wheat and the loops in green Pdb ID 4L3N), (b) SARS-CoV $(\alpha$-helices colored gray $60, \beta$-sheets green lemon, and the loops in ruby Pdb ID 2AJF) and (c) SARS$\mathrm{CoV}-2$ ( $\alpha$-helices colored yellow, $\beta$-sheets blue, and the loops in cyan Pdb ID 6M0J). Topology diagrams for the RBD of (d) MERS-CoV comprising seven $\beta$-sheets and six $\alpha$-helices, (e) SARS-CoV comprising five $\beta$-sheets and six $\alpha$-helices, and (f) SARS-CoV-2 comprising 11 $\beta$-sheets (four being shorts) and eight $\alpha$-helices. These diagrams were made using PROCHECK (www.ebi.ac.uk/pdbsum)
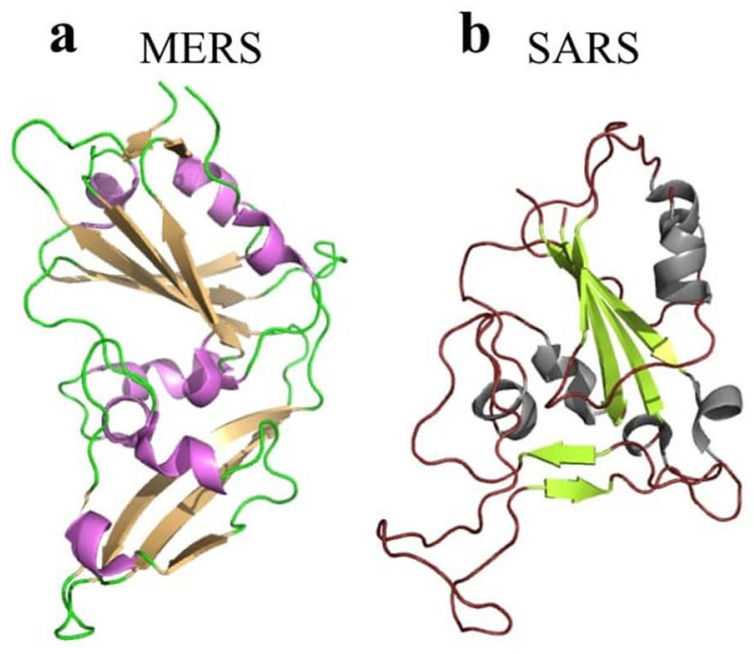

c SARS-2

d

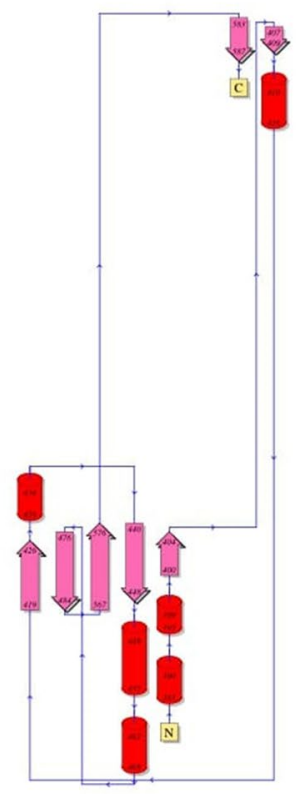

e
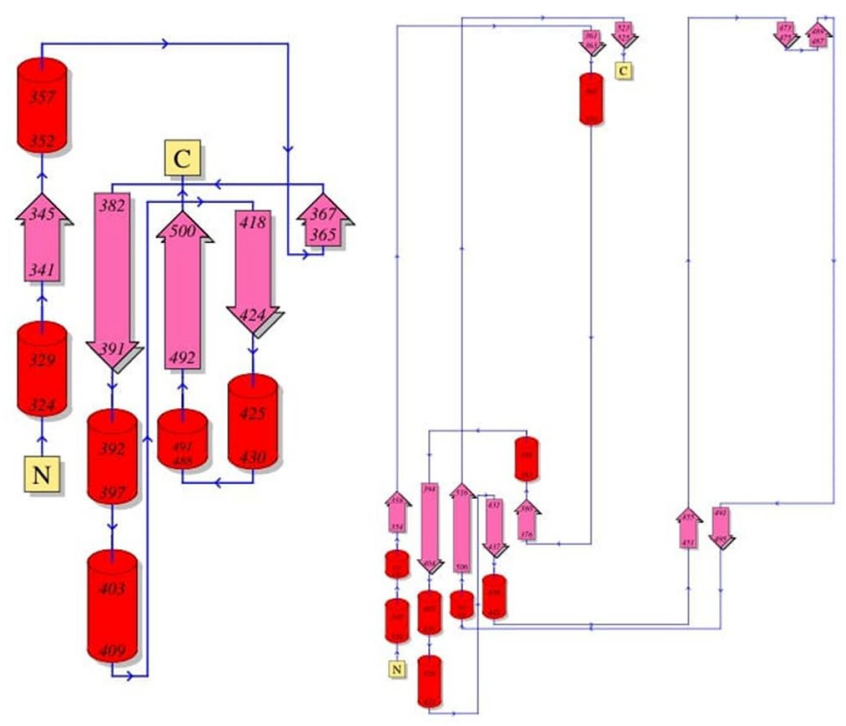

residues, where seven of them are shared between the three RBDs (Fig. 5). Preceding studies highlighted a relationship between some residues (Y442, L472, N479, and T487), the transmission process, and the binding of hACE2 to SARSCoV RBD. The residue positions are occupied with L455, F486, Q493, and N501 amino acids, respectively, in the RBD of SARS-CoV-2 (Fig. 5). Previous studies also noted that N479 and T487 residues lead to cross-species infection in the SARS-CoV-RBD (Lan et al. 2020; Li et al. 2005). The similarity in the mechanism of interactions by different RBDs toward the ACE2 receptor is demonstrated by the crystal structure of RBDs of SARS-CoV-2 and SARS-CoV complexing with the hACE2 (Lan et al. 2020; Li et al. 2005).
These two RBDs are considered to share 14 amino acids in this interaction, where eight of them are similar, including Y449/Y436, Y453/Y440, N487/N473, Y489/Y475, G496/ G482, T500/T486, G502/G488, and Y505/Y491 of SARSCoV-2/SARS-CoV, respectively.

\section{Structural protein interactions}

The S-protein N-terminal signal sequence helps this protein by guiding it to the endoplasmic reticulum. Interactions between the spike and $M$ proteins are not significant to the viral particles assembly and release. However, the release process is completed by interactions between 
Fig. 4 Superposition of MERS$\mathrm{CoV}$ and SARS-CoV RBDs on SARS-CoV-2 RBD. (a)

Illustrates the superposition of SARS-CoV RBD (gray 60 $\alpha$-helices, wheat $\beta$-sheets, and green loops) on SARS-CoV-2 RBD (yellow $\alpha$-helices, green lemon $\beta$-sheets, and ruby loops) reflecting their high degree of similarity. (b) Illustrates the superposition of MERS-CoV RBD (violet $\alpha$-helices, wheat $\beta$-sheets, and green loops) on SARS-CoV-2 RBD (yellow $\alpha$-helices, blue $\beta$-sheets, and cyan loops). These structures have less similarity and there is some place movement. (c) Illustrates the overall fold of MERS-CoV RBD (violet $\alpha$-helices, wheat $\beta$-sheets, and green loops) and SARS-CoV RBD (gray $60 \alpha$-helices, wheat $\beta$-sheets, and green loops) on SARS-CoV-2 RBD (yellow $\alpha$-helices, blue $\beta$-sheets, and cyan loops)
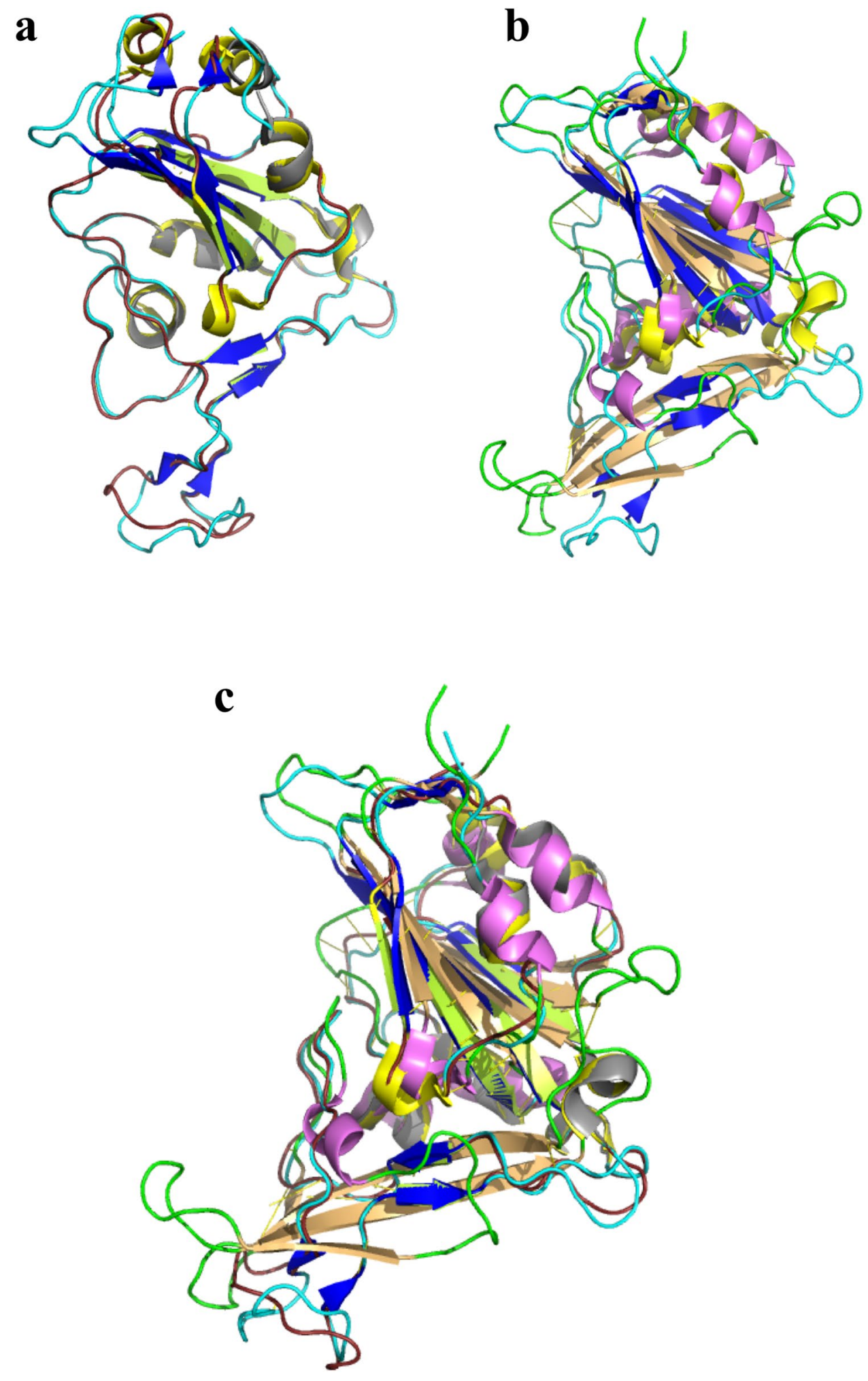

$\mathrm{M}, \mathrm{N}$, and $\mathrm{E}$ proteins. The retention of the $\mathrm{S}$ protein in the ER-Golgi intermediate compartment (ERGIC)/Golgi complex, as well as its integration into new virions, is achieved through interactions between S and M. On the other hand, interactions between $\mathrm{M}$ and $\mathrm{N}$ proteins are considered to stabilize the N-protein-RNA complex (Malik 2020). 


\begin{tabular}{|c|c|c|}
\hline SARS-COV-2 & TDAVDCALDPLSETKCTLKSFTVEKGIYQTSNFRVQPTESIVRFPNITNLCPFGEVFNAT & 345 \\
\hline SARS-COV & TDAVDCSQNPLAELKCSVKSFEIDKGIYQTSNFRVVPSGDVVRFPNITNLCPFGEVFNAT & 332 \\
\hline MERS-COV & RRAIDCGFNDLSQLHCSYESFDVESGVYSVSSFEAKPSGSVVEQAEG -VECDFSPLLSG- & 391 \\
\hline SARS-COV-2 & RFASVYAWNRKRISNCVADYSVLYNSASFSTFKCYGVSPTKLNDLCFTNVYADSFVIRGD & 405 \\
\hline SARS-COV & KFPSVYAWERKKISNCVADYSVLYNSTFFSTFKCYGVSATKLNDLCFSNVYADSFVVKGD & 392 \\
\hline MERS-COV & TPPQVYNFKRLVFTNCNYNLTKLLSLFSVNDFTCSQISPAAIASNCYSSLILDYFSYPLS & 451 \\
\hline SARS-COV-2 & EVRQIAPGQTGKIADYNYKLPDDFTGCVIAWNSNNLDSKVGGNYNYLYRLFRKSNLKPFE & 465 \\
\hline SARS-COV & DVRQIAPGQTGVIADYNYKLPDDFMGCVLAWNTRNIDATSTGNYNYKYRYLRHGKLRPFE & 452 \\
\hline \multirow[t]{2}{*}{ MERS-COV } & MKSDLSVSSAGPISQFNYKQSFSNPTCLILATVPHNLTIITKPLKYSYINKCSRLLSDDR & 511 \\
\hline & 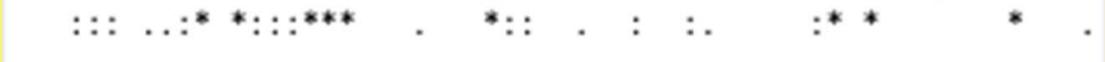 & \\
\hline SARS-COV-2 & 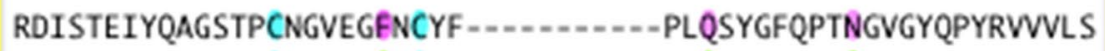 & 514 \\
\hline SARS-COV & RDISNVPFSPDGKPCTP-PALNCYW--n & 500 \\
\hline \multirow[t]{2}{*}{ MERS-COV } & TEVPQLVNANQYSPCVSIVPST-VWEDGDYYRKQLSPLEGGGWLVASGSTVAMTEQLQMG & 570 \\
\hline & $:: \quad *^{* *} \quad * \quad: \quad *^{* *}: .^{*}::^{*} \quad .::$ & \\
\hline SARS-COV-2 & FELL----HAPATVCGP----KKSTNLVKNKCVNFNFNGLTGTGVLTESNKKFLPFQQF & 565 \\
\hline SARS-COV & FELL---NAPATVCGP---KLSTDLIKNQCVNFNFNGLTGTGVLTPSSKRFQPFQQF & 551 \\
\hline \multirow[t]{2}{*}{ MERS-COV } & FGITVQYGTDTNSVCPKLEFANDTKIASQLGNCVEYSLYGVSGRGVFQNCTAVGVRQQRF & 630 \\
\hline & 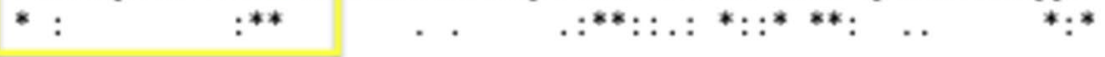 & \\
\hline
\end{tabular}

Fig. 5 Protein sequence alignment. Here, we see the similarities of RBD between SARS-CoV-2, SARS-CoV, and MERS-CoV. Conserved cysteine residues can be seen (colored cyan) and the amino acids needed for virus transmission and infection in SARS-CoV,
Y442, L472, N479, and T487 (green), which equal to L455, F486, Q493, and N501 (magenta) in SARS-CoV-2. This sequence alignment was drawn by Clustal Omega service

human cells by activating caspase- 3 and 9 , in addition to inducing ROS and activating the NF-kB signaling (Lin et al. 2006).

\section{Accessory proteins}

In SARS-CoV-2, there are around eight accessory proteins, including ORF3a, 3b, p6, 7a, 7b, 8b, 9b, and 10. The 8 a protein can be found in the SARS-CoV structure but is absent in SARS-CoV-2 (Wu et al. 2020a, b, c). Nelson and colleagues found ORF8 a and $b$ in SARS-CoV-2 as an untruncated protein (Nelson et al. 2020). On the other hand, ORF6 acts as an inhibitor of primary interferon synthesis and signaling, which mediates the human immune response against infectious agents (Yuen et al. 2020). Accessory proteins may vary between coronaviruses, elucidating the difference in their pathogenicity $(\mathrm{Li}$ et al. 2020a, b). Moreover, reports have highlighted that accessory proteins associated with $\mathrm{CoVs}$ are accountable for evasion of the host immune system (Asrani et al. 2020). 


\section{Life cycle of SARS-CoV-2}

The first step of the virus infection is its penetration into the host cell by binding S protein with the ACE2 receptor on the human cell membrane. Subsequently, the $S$ protein gets modified to enable viral fusion through the endosomal membrane. RNA is generated and translated into two types of proteins, polyproteins pp1a and pp1ab, which produces a variety of subunits of the viral replicase/transcriptase and accessory after proteolytic cleavage proteins. The viral polymerases lead to a complex of sub-genomic mRNAs by discontinuous transcription, which is finally translated into significant proteins. Eventually, genome RNAs and assembled virus particles are transported and released outside the cell through the endoplasmic reticulum and Golgi network (Fig. 6) (Shereen et al. 2020). The strategy employed by the SARS-CoV-2 to enter the cell encompasses the virus's spike glycoprotein binding to the host cell receptors using ACE2 and the cellular protease transmembrane protease serine 2 (TMPRSS2) (Djomkam et al. 2020). Based on Hoffmann and colleagues' work (Hoffmann et al. 2020), the advertised TMPRSS2 inhibitor camostat mesylate was observed to block the entry of the SARS-CoV-2 virus into the host cell.

\section{Variants of SARS-CoV-2}

Previous studies highlighted that pathogenic viruses undergo mutations to adapt to their host by evading the immune system and increasing their infectivity. During the initial phases of the pandemic, one study (Korber et al. 2020) informed the presence of 14 mutations associated with the $S$ protein. Out of these 14 mutations, only one mutation (the D614G) proved to be essential in increasing the virus incidence and global spread (Korber et al. 2020). Another mutation identified as V367F was considered to increase the virus's interactions with the hACE2 receptor, thereby increasing the viral infectivity and entry (Ou et al. 2021). By the end of 2020, more than 4000 versions of SARS-CoV-2 have been identified across the globe. However, the most prominent variants carry mutations associated with the S protein, particularly the RBD, responsible for the main interactions between the virus and the human cells through the ACE2 receptor. Table 2 summarizes the SARS-CoV-2 variants based on recent reports. The variants of SARS-CoV-2 have been isolated, identified, investigated, and studied. The analysis of these investigations shows that mutations related to the $\mathrm{S}$ protein enable the virus to resist the antibodies and enhance person-to-person transmission by approximately $40 \%$ to $70 \%$

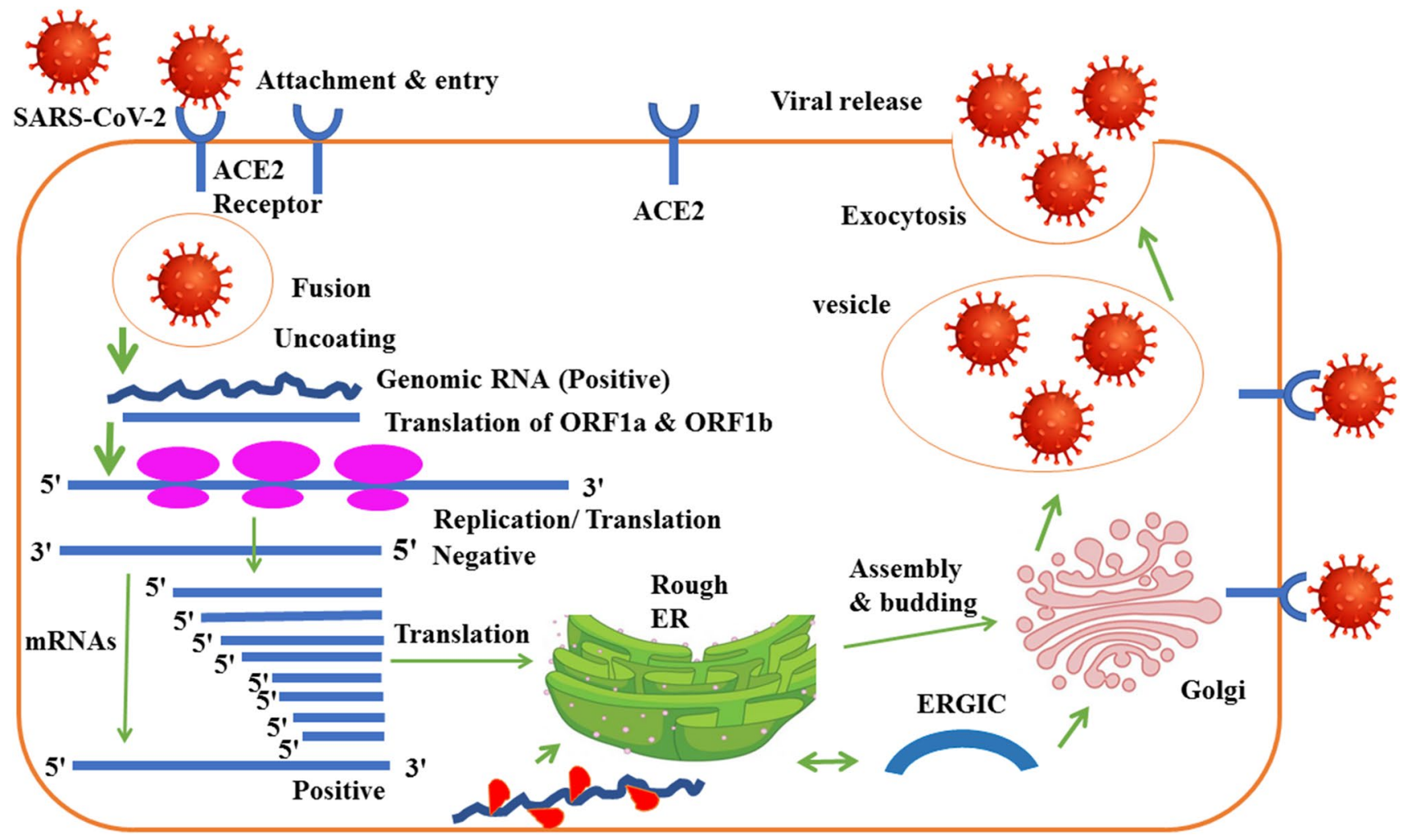

Fig. 6 Illustrates the SARS-CoV-2 life cycle and the way the virus enters human cells and replicates itself. ACE2, angiotensin-converting enzyme 2; ER, endoplasmic reticulum; ERGIC, ER-Golgi intermediate compartment 
Table 2 The SARS-CoV-2 variants that spread globally, the detection place, and the emerging date (https://www. who.int/en/activities/track ing-SARS-CoV-2-variants/, accessed August 8, 2021)

\begin{tabular}{|c|c|c|}
\hline SARS-CoV-2 variants and lineages & Detection place & Emerging date \\
\hline $\begin{array}{l}\text { Variant with double mutations (L452R and E484Q) } \\
\text { B.1.617.1 ( } \chi \text {, delta) and B.1.617.2 }(\delta \text {, kappa) }\end{array}$ & Maharashtra, India & Mar 2021 \\
\hline (20C/S:452R) B.1.427/B.1.429 ( $\varepsilon$, epsilon) & California, USA & Feb 2021 \\
\hline (20I/501Y.V1) B.1.17 ( $\alpha$, alpha) & UK & Mid-Dec 2020 \\
\hline$(20 \mathrm{H} / 501 \mathrm{Y} . \mathrm{V} 2)$ B.1.351 ( $\beta$, beta) & South Africa & Dec 2020 \\
\hline (20 J/501Y.V3) P.1 ( $\gamma$, gamma) & Brazil & Dec 2020 \\
\hline (E484K/S477N) B.1.526 (1, Iota) & New York, USA & Late-Nov 2020 \\
\hline (20G/677H/P) B.1.2 & New Mexico and Louisiana & Aug and Oct 2020 \\
\hline
\end{tabular}

(Fontanet et al. 2021; Deng et al. 2021; Wise 2020; Tegally et al. 2020; Faria et al. 2021; West et al. 2021; Hodcroft et al. 2021; Kirola 2021). For instance, according to the structural studies, the Q677 amino acid that mutated to histidine or proline in New Mexico and Louisiana variants lies within a flexible part of the $\mathrm{S} 1 / \mathrm{S} 2$ cleavage site. The mutated residues stimulate cleavage located in the S1/S2 site, which is considered to provide the dynamic conformational changes that increase the interactions between the $\mathrm{S}$ protein and hACE2 receptor (Tegally et al. 2020). The WHO group preferred using letters of the Greek alphabet for identifying the variants in a simple way (Table 2).

\section{The power of coronaviruses}

Coronaviruses are powerful infectious agents as they can jump between species and infect different cells (Tang et al. 2015). The virus entry into the host cells is mediated by the $\mathrm{S}$ glycoprotein, which is believed to have both receptor binding and membrane fusion capabilities (Masters 2019). Furthermore, the virus utilizes various steps to infect human targeted cells, including proteolytic activation of the $\mathrm{S}$ protein with the help of host cell proteases, such as endosomal cathepsins, cell surface transmembrane protease/serine (TMPRSS) proteases, furin, and trypsin (Millet and Whittaker 2014). Inhibition of these host-cell proteases has been reported to prevent the virus from entering the cells (Adedeji et al. 2013). Two cleavage sites are found within the $S 2$ domain of the spike protein (Fig. 7).

The first cleavage site occurs to separate the RBD and fusion domain (Bosch et al. 2003), while the second one occurs to expose the fusion peptide at $\mathrm{S} 2$, which attaches to the host cell membrane (Wrapp et al. 2020). The SARSCoV-2 is believed to utilize the human furin enzyme in entering host cells through a cleavage site in the junction of the $\mathrm{S} 1 / \mathrm{S} 2$ domains. Furin is a member of the proprotein convertases (PC) family that can cleave single or paired basic amino acids within the motif R/K-(X)0,2,4,6-R/K (where X refers to any residue) (Seidah and Prat 2012). The favorable recognition site for the furin enzyme is the
RXR/KR motif, which requires the furin binding pocket's occupation with arginine residue at the $\mathrm{P} 1$ and $\mathrm{P} 4$ positions and lysine amino acid at P2 (Henrich et al. 2003). Moreover, studies have found that increasing the arginine content in penetration peptides enhances cellular uptake (Wender et al. 2000; Esbjörner et al. 2007). The presence of the furin-like site (RRAR) in the SARS-CoV-2 $S$ protein (Fig. 7) provides the virus with a $100-1000$ increased chance to penetrate through the host cell compared to SARS-CoV, which lacks RRAR site (Cyranoski 2020). Furthermore, SARS-CoV-2 possesses a 10-20 times greater ability to bind the ACE2 receptor compared to SARS-CoV (Cantuti-Castelvetri et al. 2020), encouraging some researchers to explore the presence of a second receptor utilized by SARS-CoV-2 to interact with the human cells (Cantuti-Castelvetri et al. 2020). Two recent published studies highlighted another host cell receptor known as neuropilin-1 (NRP1) that is typically expressed in a wide range of human tissues, including neurons, blood vessels, and respiratory epithelium cells. This new receptor necessitates a furin-cleaved substrate with a conserved carboxyterminal sequence (RRAR) for its action. This peptide motif follows the C-end rule (CendR) when binding to NRP1 and NRP2 receptors, thereby increasing the SARS-CoV-2 entry and infectivity (Song et al. 2019; Cheng et al. 2019). Likewise, investigators have demonstrated the presence of other human cell receptors that could be utilized by SARS-CoV to infect and enter into the host cells, including the dendritic cell-specific intercellular adhesion molecular-3-grabbing non-integrin (DC-SIGN) and/or liver/lymph node-SIGN (L-SIGN). However, their interactions with human cells differ from those of the ACE2 receptor (Vavougios 2020) and mutations around the $\mathrm{S}$ protein cleavage sites may impact cellular tropism and pathogenesis ( $\mathrm{Li}$ et al. 2020a, b). The alignment of the SARS-CoV-2 $S$ protein sequence with sequences obtained from SARS-CoV and SARS-like viruses revealed the presence of four amino acids upstream of the single arginine cleavage site 1 in SARS-CoV-2 that corresponds with a canonical furin-like cleavage site (Izaguirre 2019). This site could be inserted into the SARS-CoV-2 S protein 


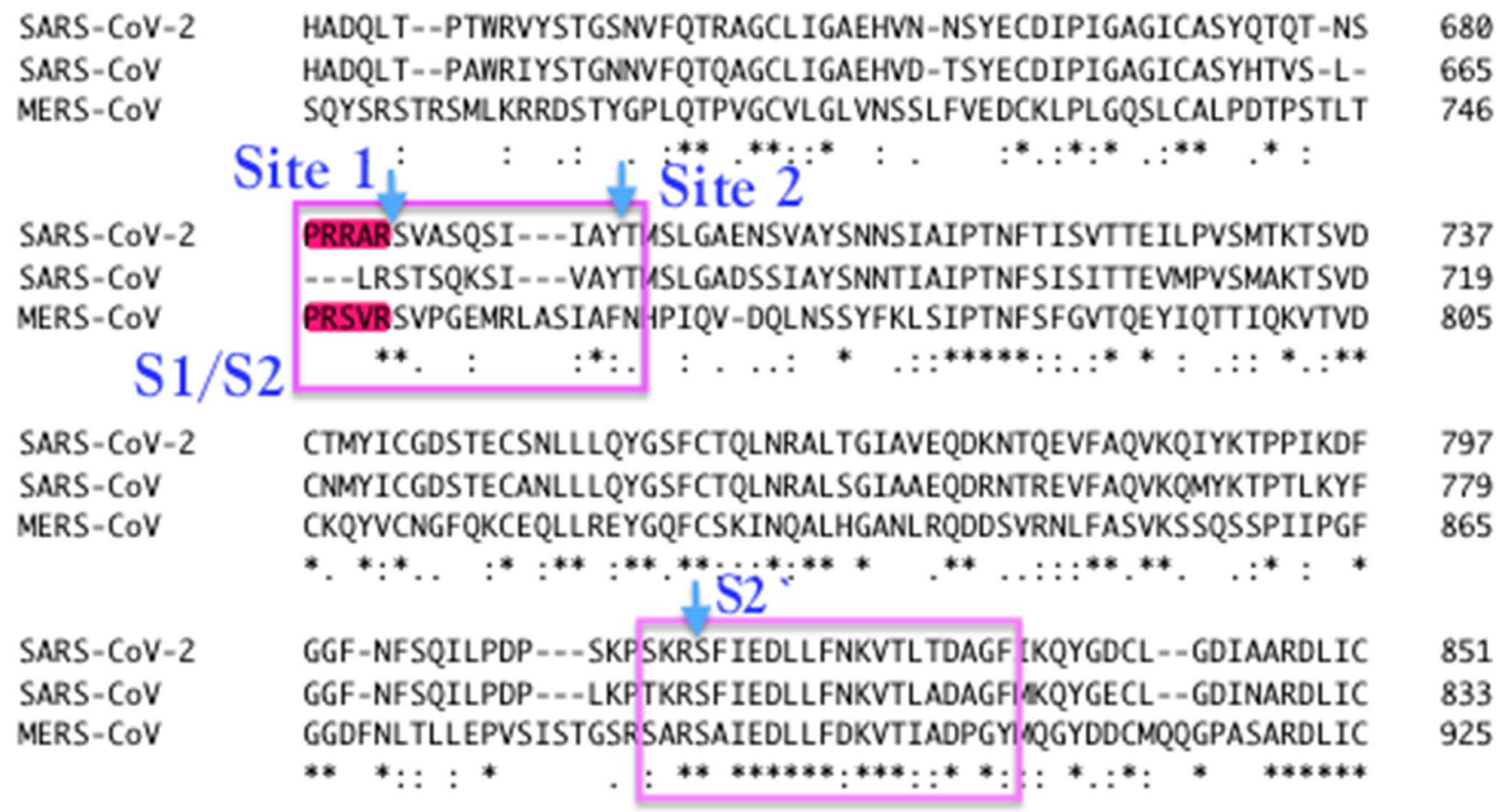

Fig. 7 Protein sequence alignment. This illustrates the cleavage sites that exist within S2 domain of spike protein in the three SARSCoVs. The initial cleavage separates the RBD and fusion domain and the next exposes the fusion protein. The furin-like site (colored red) appears in SARS-CoV-2 and MERS-CoV, but not in SARS-CoV. The figure was created using Clustal Omega sequence through natural recombination and cleaved by furin enzyme during virus entry into the host cell (Izaguirre 2019). This study has analyzed the presence of a furinlike cleavage site in the $\mathrm{S}$ protein of recently emerged coronaviruses, SARS-CoV-2, SARS-CoV, and MERS-CoV, using the Clustal omega tool. The results confirmed its absence in SARS-CoV and its presence in the other two coronaviruses (Fig. 7). According to WHO, the SARS$\mathrm{CoV}$ epidemic infected approximately 8098 persons in 29 countries and caused 916 (11.3\%) deaths (Chan-Yeung and $\mathrm{Xu}$ 2003), while MERS-CoV spread in 27 countries and infected 2468 individuals from 2012/2013 to May 2019 with 851 (35\%) deaths (WHO 2019). These data show that MERS-CoV is more pathogenic than SARS-CoV, which can be explained by the presence of a furin-like cleavage site. Moreover, viral membrane components play a vital role in infection, viral entry, and the formation of multinucleated cells referred to as syncytia (Sanders et al. 2021). Cholesterol is one of the significant crucial viral membrane contents found essential in the fusion process through a raft-independent mechanism where it creates synapse-like clusters with the human ACE2 receptor. Sanders and colleagues also noted the presence of unusual membrane-proximal regions (aromatic, cysteine, hydrophobic, non-charged hydrophilic, and proline amino acids) of spike needed for fusion mechanism (Sanders et al. 2021).

\section{Why do some patients have COVID-19 symptoms while others do not?}

Some individuals who contract the SARS-CoV-2 and have a positive diagnosis are asymptomatic, i.e., they do not exhibit any symptoms and their health is not affected in any way. However, other patients exhibit a wide range of serious symptoms and may even die. It must be asked why the reaction to the virus varies so much between individuals. Pollàn et al. (2020) found that between 21.9 and $35.8 \%$ of patients were asymptomatic, with this cohort representing between 367,000 and $1,042,000$ cases in Italy. It is interesting to note that five independent reports from different nations, the USA (Grifoni et al. 2020), Netherlands (Weiskopf et al. 2020), Germany (Braun et al. 2020), Singapore (Le Bert et al. 2020), and the UK (Meckiff et al. 2020), found that individuals not suffering the infection still had SARS-CoV2-S specific $\mathrm{T}$ cells, which could be derived from memory $\mathrm{T}$ cells created by historic infections with the global coronavirus that causes the common cold. In different groups of people suffering SARS-CoV-2, $80 \%$ have no or only mild 
symptoms, $15 \%$ have severe symptoms and require supplementary oxygen, and 5\% have critical symptoms requiring ventilation and other forms of invasive treatment (Rokni et al 2020). Dong et al. (2020) reviewed 11 patients infected with COVID-19 who had responded in various ways to the virus and displayed a range of symptoms. Some of the patients had a mild case of the virus, with no pneumonia; others were suffering COVID-19 pneumonia but did not have any virus showing in their samples. Certain patients experienced standard cold symptoms for a short time, testing negative for SARS-CoV-2, but subsequently (within the next 14 days) returned positive tests; these patients are regarded as longterm virus carriers and went on to experience moderate cases of COVID-19 pneumonia (Bai et al. 2020).

\section{How can COVID-19 be treated?}

\section{SARS-CoV-2 detection and COVID-19 diagnosis}

Because the spread of most of the COVID-19 population occurs without symptoms, identifying infected persons is difficult (Anderson et al 2020). The rapid spread of SARSCoV-2 necessitates the development of more rapid, simple, and sensitive detection methods. The RNA-dependent RNA polymerase (RdRP), N, E, and S proteins of the virus are encoded by genes that may be detected using reverse-transcription PCR (RT-PCR) (Chan et al 2020).

\section{Molecular diagnosis of COVID-19}

In molecular diagnosis, there are three primary aspects to consider: (1) reducing the number of false negatives by detecting small amounts of viral RNA; (2) avoiding the number of false positives by correctly identifying positive signals from different infections; (3) a high capacity for testing a large number of samples quickly and effectively (Caruana et al 2020). The quality and relevant abundance of RNA in collected samples are crucial for the sensitivity of molecular COVID-19 tests (Loeffelholz and Tang 2020). Moreover, the identification of SARS-CoV-2 genetic material (RNA) is used to diagnose COVID-19 at the molecular level (Carter et al 2020) and the detection of viral proteins is also important in the diagnosis of COVID-19; however, it has not yet been used (Feng et al 2020).

\section{SARS-CoV-2 genome-based diagnostics}

Now that the SARS-CoV-2 complete genome sequence has been given to public databases, researchers may find it easier to create primers and probes for COVID-19 diagnostic procedures. RT-PCR was the first approach for diagnosing COVID-19 (Corman et al 2020). Alternative exponential amplification procedures do not require thermal cycling and can be conducted at a single temperature. These approaches include isothermal nucleic acid amplification (IA), rolling circle amplification (RCA), recombinase polymerase amplification (RPA), exponential strand displacement amplification (ESDA), and exponential amplification reaction (EAR) (Feng et al 2020). For detecting small amounts of nucleic acids, LAMP and RPA give equivalent sensitivity to PCR more than other techniques (Zhao et al 2015). To evade cross-reaction with other human coronaviruses and potential SARS-CoV-2, WHO advised detecting two distinct genes of the COVID-19 virus genome: one specific for SARS-CoV-2 and the other nonspecific for detecting other CoVs (WHO 2020a, b). RdRp is the most sensitive and effective target for detecting SARS-CoV-2, and its tests have been validated in numerous laboratories (Caruana et al 2020). Ishige et al. (2020) used three genes in the (rRT-PCR) assay for SARSCoV-2 RNA detection: the SARS-CoV-2 specific N gene, the Sarbecovirus specific E gene, and the human ABL1 gene as a control. Furthermore, Chan et al. (2020) suggested a new RT-PCR test based on the RdRp/Hel for identifying small amounts of SARS-CoV-2 in plasma and saliva swabs without interfering with the other viruses.

\section{Detection of SARS-CoV-2 based on clustered regularly interspaced short palindromic repeats (CRISPR)}

CRISPR-based approaches are now in use or have the potential to be used as a POC testing option for pathogens such as SARS-CoV-2. Researchers were enticed to design and construct diagnosis and therapy programs that focus on effective CRISPR technology because of its speed, precision, specificity, strength, efficiency, and diversity (Rahimi et al 2021). CRISPR COVID's finding has been demonstrated to have similar specificity and sensitivity to RT-PCR and nucleic acid sequence analysis (Hou et al 2020). According to the Cas protein type and the nucleic acid (DNA or RNA) that works on it, the CRISPR system is categorized into two primary groups and six different types (Rahimi et al 2021). AllIn-One Dual CRISPR-Cas12a (AIOD-CRISPR) is a potential pathogen identification tool. When the Cas 12a crRNA complex binds to the specific sequence, active Cas12a cleaves surrounding ssDNA, resulting in a fluorescence signal. Within $40 \mathrm{~min}$, this test could identify low concentration (1.3 copies) of the $\mathrm{N}$ gene using real-time detection or visual method (Ding et al 2020). Another sensitive pathogen detection technique based on CRISPR and approved by the FDA as the first technique for SARS-CoV-2 and COVID19 identification is the Specific High Sensitivity Enzymatic Reporter UnLOCKing (SHERLOCK) (Gootenberg et al. 2017). This type of tool was presented by Zhang et al. (2020a, b) and takes less than an hour to complete. The DNA endonuclease targeted CRISPR trans reporter (DETECTR) 
test is another detection method. It was created to perform the simultaneous reverse transcription and isothermal amplification of RNA taken from nasopharyngeal swabs using RTLAMP, followed by virus detection using Cas 12 (Broughton et al 2020). Wang et al. (2020a, b, c) also created a CRISPR/ Cas12a-based technology (CRISPR/Cas12a-NER) that can be read with the naked eye, does not require a specialist device, completed in a short time (40 min), and can identify at least ten copies of a viral. In addition, Huang et al. (2020a, b) represented the CRISPR-FDS test using the same system (CRISPR/ Cas12a) and the reading was carried out using fluorescent plate readers. CREST is the term given to a CRISPR Cas13-based diagnostic technique (Cas13-based, rugged, equitable, scalable testing). It relies on readily available protein and fluorescent probes, making it a competitive and accessible detection method (Rauch et al. 2021). Cas13a direct detection assay is another technique based on Cas 13a, amplification-free and using a smartphone for identifying SARS-CoV-2 in less than half an hour (Fozouni et al 2020). Furthermore, the Cellphone-Based Amplification-Free System with CRISPR/CAS-Dependent Enzymatic (CASCADE) test is based on the Cas12-mediated transcleavage of a catalase: single-stranded DNA probe in response to the recognition of a specific nucleic acid target, such as SARS-CoV-2 genomic RNA. This generates a gas signal, which is subsequently identified using a smartphone-specific application and camera (Silva et al 2021).

The use of CRISPR systems in molecular diagnostics and detection has developed, and Rahimi et al. (2021) and Gupta et al. (2021) have extensively described several CRISPRbased diagnostic methods for identifying COVID-19.

\section{Next-generation sequencing (NGS) and SARS-CoV-2 detection}

Next-generation sequencing (NGS) is a technique used to analyze and sequence nucleic acids (DNA/RNA) and has made a big advancement in molecular biology. It is a fast, cheap, and scalable technique that allowed for investigating a wide range of biological research and studies that were previously impossible. In addition, the NGS can detect and recognize the identified viruses and/or undiscovered novel ones (Chiu 2013). This technique was used by Zhou and coworkers to acquire viruses from seven patients with severe pneumonia, and full-length sequencing was performed on an RNA sample (Zhou et al 2020). Aynaud et al. also report "Systematic Parallel Analysis of RNA connected to Sequencing for COVID-19 screening" (C19-SPAR-Seq) that can analyze a huge number of infected individual samples in one run with a sensitivity of 91 to $>95 \%$ and a specificity of $100 \%$ (Aynaud et al 2021). In general, this technology is insufficient when quick analysis and results are needed compared to RT-PCR (Thorburn et al 2015).

\section{COVID-19 diagnosis using viral proteins}

COVID-19 can be diagnosed using SARS-CoV-2 proteins like antigens or by looking for antibodies in the patient's blood during a specific time frame that is produced in response to viral infection (To et al 2020). Cross-reactivity with various antibodies developed against SARS-CoV-2 and other coronaviruses, on the other hand, is a problem. Antigen-detecting diagnostic tests have been developed as both laboratory-based tests and rapid diagnostic tests (RDTs) for POC (FIND 2020).

To describe the immunoglobulin $(\operatorname{IgG})$ and $(\operatorname{IgM})$ reactions in patients, Jiang and colleagues created a SARS$\mathrm{CoV}-2$ proteome microarray. IgM and IgG antibodies that detect and bind SARS-CoV-2 proteins were found in the samples (Jiang et al 2020). Also, Ju et al. (2020) described the identification of 206 RBD-specific monoclonal antibodies (mAbs) found in eight SARS-CoV-2 patient samples. These mAbs neutralize SARS-CoV-2 and prevent the interaction of hACE2 with RBD, without cross-reactivity with SARS-CoV and/or MERS RBDs. In addition, Zhao et al. (2020a, b) employed ELISA works on a double antigen sandwich test for investigating the presence of $\operatorname{IgM}$ and $\operatorname{IgG}$ with 99\% sensitivity. Furthermore, FDA authorized lots of kits based on different approaches for emergency use that can be found in the market, as mentioned in Islam and Iqbal (2020). In addition, Murugan et al. (2020) developed a plasmonic fiber-optic absorbance biosensor (P-FAB) system lined with gold nanoparticles. It uses saliva samples for COVID-19 diagnosis by determining the virus or its $\mathrm{N}$ protein directly in one step, low SARS-CoV-2 concentration, and limited sample preparation steps. In addition, antibody attachment on polyaniline or gold nanoparticle-coated fiber optics for specific detection of viral proteins in the samples would change the refractive index in the surrounding environment, resulting in a change in intensity of light or absorbance. To identify IgG/IgM in collected samples, viral capsid protein is also adsorbed on the optical fiber surface. The detection limit in such a situation, according to the researchers, was $100 \mathrm{U} / \mathrm{ml}$ in $60 \mathrm{~min}$ (Nag et al 2020). Moreover, SARSCoV-2 RapidPlex is a revolutionary multiplexed, portable, electrochemical graphene-based platform for ultra-fast diagnosis of COVID-19. It detects $\mathrm{N}$ protein antigen, $\mathrm{S} 1-\mathrm{IgG} /$ $\mathrm{IgM}$, and C-reactive protein (CRP) within physiologically relevant ranges in both blood and saliva (Torrente-Rodríguez et al 2020).

\section{Lateral flow assay (LFA)}

LFA technology is important in POC testing since it is fast and inexpensive with a simple procedure that can be used by untrained individuals. It is divided into three types. The first type is lateral flow immunoassay (LFIA) for detecting 
antibodies/antigens used by Xiang et al. (2020) for SARS$\mathrm{CoV}-2$ detection. The second type which is nucleic acid lateral flow assay (NLFA) detects nucleic acid using a DNA or RNA probe like SHERLOCK and AIOD-CRISPR protocols. The final one which is nucleic acid lateral flow immunoassay (NALFIA) uses both antibodies/antigens and nucleic acid as biomarkers (Antiochia 2021).

\section{Nanotechnology and COVID-19}

Nanotechnology opens a slew of possibilities for developing or creating highly effective and beneficial disinfection systems. Unhygienic surfaces especially in public places such as schools, public transportation, and parks are familiar sites for the outbreak of common infectious disease (Campos et al 2020; Dancer 2014). Surface coating made from nanomaterials has been proven to have the capability of avoiding various infections in numerous studies (Basak and Packirisamy 2020). Investigations that primarily dwell on nanotechnology for the creation of materials have opened new-fangled perceptions of having surfaces with inbuilt selfcleaning properties (Querido et al 2019). The systems have antimicrobial activity fittings, which slowly emit chemical disinfectants while enhancing their active period. Furthermore, they may be engineered in certain ways to enhance their responsive features that help distribute active materials in response to various stimuli, for example, photocatalytic, electrothermal, photothermal, and other responses (Geyer et al 2020). Vaze et al. (2019) innovated nano-disinfectants basing their craft on engineered water nanostructures (EWNS). The generation of these nano-based structures was through electro-spraying followed by an aqueous suspension ionization process of the various active ingredients. The created nanomaterials were examined on the H1N1 influenza virus and they gave better outcomes in decreasing pathogen concentration. Some metallic nanoparticles especially silver nanoparticles have demonstrated enhanced or comprehensive action mechanisms against viruses as well as other microorganisms (Dyshlyuk et al 2020). Numerous companies are now using nanotechnology in their production processes; one of them, for example, used disinfectant formulation based on silver and titanium dioxide nanoparticles. As stated by the company, their formulations permit selfsterilization of surfaces and were recently applied at some point for cleaning various buildings in Milan during the COVID-19 pandemic (StatNano 2020a). Likewise, another company devised a new self-cleaning system that relies on crystal nanoparticles that are non-toxic system and produce no residues (StatNano 2020b).

When it comes to a viral outbreak, the frontline workers, such as health workers, need proper protection. This is an area that requires vicious integration of antimicrobial technology with personal protective clothing to enhance healthcare workers' safety and security (Coté et al 2020). Nanotechnologies offer novel materials that are resistant, comfortable as well as safe in terms of offering guard against chemical and biological risks (Yetisen et al 2016; Spagnol et al 2018). Medical or laboratory aprons, facemasks, and other medical wear are nanoengineered to offer new functions, for example, antimicrobial activity and hydrophobicity without interfering with the fabric's breathability and texture. Including hydrophobicity to a piece of a fabric involves using millions of miniature fibers called nanowhiskers, made from hydrocarbons that are three times smaller than typical cotton fiber. This enhances the fabric's surface tension, inhibiting the absorption of liquid droplets. Some methodologies encompass nanoscale 3D structures on material surfaces coating them with hydrophobic nanoparticles (Yetisen et al 2016; Mansi et al 2019).

\section{SARS-CoV-2 detection, diagnosis, and drug delivery systems-based nanotechnology}

Nanotechnology can be used to develop sensors that can quickly detect SARS-CoV-2, greatly reducing the need for time-consuming conventional diagnostic testing. Gold nanoparticles, iron oxide nanoparticles, graphene, quantum dots, carbon quantum dots, and carbon nanotubes have all been investigated as potential sensors for the detection of SARS-CoV-2 (Xiang et al. 2020; Srivastava et al. 2021). Research is also ongoing into the potential of fabricating nanofiber masks as active filters for controlling airborne viruses (Tebyetekerwa et al. 2020). There is a potential for providing active protection against the virus by synthesizing nanoscale coating materials to be used on a range of personal protective equipment for medical personnel (Karim et al. 2020).

The techniques used in extracting viral RNA are likewise the focus of the application of nanotechnology in viral detection. Research has proven that magnetic nanoparticles lined with silica may be used to speedily extract RNA molecules from the virus in affected individuals for detection using the RT-PCR method (Zhao et al 2020a, b; Brazilchuck 2020). This cuts the prolonged processes involved in RNA extraction and it also makes the technique very sensitive (Brazilchuck 2020). Different types of nanomaterials, such as quantum dots, carbon nanotubes, silica nanoparticles, polymeric nanoparticles, and metallic nanoparticles, are widely used for viral detection. During the development of these systems, nanoparticle surfaces are primarily customized using biomolecules that are derived from the virus like peptide, antigen, antibody, RNA, or DNA (Draz and Shafiee 2018; Halfpenny and Wright 2010). Because nanoparticles have a high surface area to volume ratio, there 
are more interactions between the sample and the sensors, which increase the limit of detection while decreasing the duration (Talebian et al 2020). In addition, utilizing hybrid systems which enable a combination of various biomolecules stemming from viruses with nanoparticles allows for the development of sensitive sensors (Draz and Shafiee 2018). Moitra et al. (2020) designed a selective technique that enhanced SARS-CoV-2 identification with bare eyes. The assays rely on thiol-improved antisense oligonucleotides (ASOs) coated on gold nanoparticles and are sensitive in detecting the $\mathrm{N}$ gene of SARS-CoV-2, detecting a positive case within $10 \mathrm{~min}$. Moreover, Seo et al. (2020) fashioned a SARS-CoV-2 sensor that detected the virus without initial pre-treatment of samples by using graphene nanosheets fixated with specific antibodies that act against the $S$ protein. Samples from nasopharyngeal swabs having COVID-19 and those from cultured virus and antigenic protein were used for device authentication. The device detected the $\mathrm{S}$ protein, known to be found in SARS-CoV-2 in miniature concentrations of about $1 \mathrm{fg} / \mathrm{mL}$ in saline buffered media. In addition, a detection limit of $2.42 \times 10^{2}$ copies $/ \mathrm{mL}$ was realized from the clinical samples. Currently, there are at least 90 antiviral drugs approved for use against viral infections. However, water solubility and adverse effects are a problem for drug administration, preventing the effective use of the drugs (De Clercq and Li 2016). The many side effects due to the use of antiviral medications are due to their accumulation, especially in the off-target tissues (Lembo et al 2018). Often drugs having nano-based carrier systems are very efficient antiviral formulations that help lessen toxicity and side effects of the standard treatment of viral diseases. Also, it is likely to diminish the rate of resistance development by encapsulation of these nano-drugs (Lembo et al 2018; Singh et al 2017).

Nanomaterials are subject to alteration or modification to have or bear different functional groups on their surfaces which help them bond with specific receptors. These approaches are handy when blocking the target cell-virus contact. Nanoparticles are multifunctional and can operate as an antigen carrier as well as perform the role of an adjuvant in various instances, hence becoming sufficient tools in releasing important compounds in targeted sites (Vijayan et al 2019). These structures may be developed to cross the cell membranes and, in the process, target exclusive subcellular sites enhancing the possible development of nanobased vaccines. Therefore, several materials have the proficiency for developing nanocarriers, such as polysaccharides and polymers (Shin et al 2020). The lipidic nanoparticles used in the encapsulation of genes improve vaccine immunological compliance by preserving the RNA or DNA from enzymatic action, which leads to degradation and increasing cell absorption, allowing the genetic substance to be discharged into the target cell (Moon et al 2012).

\section{Treatment of COVID-19}

Globally, scientists have been in a race against time to discover cures and vaccines for COVID-19 stemming from SARS-CoV-2, and these initiatives are ongoing. Governments have employed a variety of strategies to combat the disease and deal with patients. Several treatment protocols have been created, which include the use of anti-viral medication such as lopinavir (Yao et al. 2020a, b), ribavirin (Falzarano et al. 2013), and remdesivir (Holshueet al. 2020). Lopinavir and ribavirin both suppress the viral proteins needed for the virus to replicate, while remdesivir targets the genome of the virus. In addition, chloroquine (Gao et al. 2020), hydroxychloroquine (Yao et al. 2020a, b), and corticosteroids (Huang et al. 2020a, b) have been employed. Chinese physicians created novel protocols employing antibodies (Tian et al. 2020) and convalescent plasma transfusion (Ye et al. 2020).

Esparza et al. (2020) researched nanobodies (NIHCoVnb-112) having a molecular weight of $12-15 \mathrm{kDa}$ and a single-domain antibody fragment taken from llamas that had been immunized with S1 of spike protein. Such nanobodies have the capacity to bind with SARS-CoV-2 RBD, abolishing viral interactions with hACE2. In addition, they demonstrated a capacity for binding with several versions of $S$ protein which prevents cell entry by virus's variants. The researchers stated that producing these nanobodies was economical in comparison to alternative vaccines or antibodies against SARS-CoV-2 (Esparza et al 2020).

\section{Types of vaccines}

Over recent years, technological and biotechnological developments have permitted the creation of vaccines and drugs using molecular biology. Such vaccines generally fall into three categories, as seen in Table 3 (WHO guidance document 2021). Globally, several pharmaceutical companies and laboratories have been working to find safe workable vaccines against SARS-CoV-2. China was the first country to license a vaccine, as a result of being the frontline country in the pandemic; this vaccine was only used on Chinese military personnel. Moderna therapeutics was one of the first major pharmaceutical companies to begin evaluations of the possibility of using their vaccine, mRNA-1273, with humans (Jackson et al. 2020). The vaccine is a non-replicating RNA vaccine resulting from collaboration with the NIH Vaccine Research Centre. It induces SARS-CoV-2 S protein in human bodies, stimulating the immune system to produce anti-viral protein antibodies. As of February 2021, over 200 COVID-19 vaccines were being developed globally, with approximately 110 being in clinical development. At present, there are 
Table 3 Different types of vaccines with descriptions and examples of each one (WHO newsroom 2021)

\begin{tabular}{|c|c|}
\hline Vaccine type & 1. Live virus and inactivated vaccine \\
\hline Description & $\begin{array}{l}\text { Live virus vaccine depends on using a weakened live virus that caused the disease and manufacturing it in scale. } \\
\text { In contrast, inactivated virus vaccine involves dead virus. These types of vaccines face safety issues }\end{array}$ \\
\hline Examples & $\begin{array}{l}\text { Chickenpox, shingles, and measles are examples for vaccines containing live viruses while flu and polio are } \\
\text { examples of inactivated virus vaccines }\end{array}$ \\
\hline COVID-19 vaccines example: & $\begin{array}{l}\text { Inactivated virus vaccines for COVID-19 are InCoV, developed by Sinopharm/BIBP and another manufactured } \\
\text { by Sinovac, both of them still in development. Vero Cell is developed by IMBCAMS, China and still under } \\
\text { initial development }\end{array}$ \\
\hline Vaccine type & 2. Viral vector vaccines \\
\hline Description & $\begin{array}{l}\text { This type depends on the engineering of a human safe and harmless virus that will serve as a vector to carry one } \\
\text { or more of the pathogen-specific proteins. This virus is then injected into the body, which will trigger the host } \\
\text { immune system to produce antibodies against the microbe. This type of vaccine is safer than the first one but } \\
\text { has a problem with large-scale production }\end{array}$ \\
\hline Examples & Ebola vaccine \\
\hline COVID-19 vaccines example & $\begin{array}{l}\text { Most SARS-CoV-2 vaccines are classified under this type. AZD1222, CoviShield, Ad26.COV2.S, Ad5-nCoV, } \\
\text { and Sputnik V are examples of this vaccine section }\end{array}$ \\
\hline Vaccine type & 3. Nucleic acid vaccines \\
\hline Description & $\begin{array}{l}\text { This is a new technique used in the production of vaccines and it was available before COVID-19 pandemic. The } \\
\text { vaccine is designed according to one or more specific viral genes, which will then be injected into the human } \\
\text { body to produce a specific protein(s) that will stimulate the immune system to synthesize new antibodies. This } \\
\text { type has some limitations such as the complex delivery system, requiring high doses, and difficult procedure } \\
\text { for preparing and producing }\end{array}$ \\
\hline Examples & Have not been used in human before 2020 \\
\hline COVID-19 vaccines example & $\begin{array}{l}\text { BNT162b2 developed by Pfizer Inc and BioNTech SE companies. Also, Moderna developed mRNA-1273 (Jack- } \\
\text { son et al. 2020) }\end{array}$ \\
\hline
\end{tabular}

seven vaccines against COVID-19 being used around the world of different sorts, with others expected to be added. Table 4 shows the COVID-19 vaccines currently being used clinically (as of August 2021) (WHO guidance document 2021).

\section{COVID-19 and the environment}

Pollution, which is caused by human activities and modern lifestyles, has had an impact on environmental systems with common examples being water, air, soil, and food, reducing the human life expectancy and causing a variety of illnesses.

Table 4 Some of the COVID-19 vaccines used currently in the globe (WHO Guidance document 2021)

\begin{tabular}{|c|c|c|c|c|}
\hline Vaccine name & Developer company & Number of doses & Efficiency & Authorization and using date \\
\hline Cansino & $\begin{array}{l}\text { Cansino Biologics and Beijing Institute of Biotech- } \\
\text { nology }\end{array}$ & 1 dose & $65.7 \%$ & June 2020 in China \\
\hline Covaxin & $\begin{array}{l}\text { Bharat Biotech, the Indian Council of Medical } \\
\text { Research, and the National Institute of Virology }\end{array}$ & 2 doses/4 weeks apart & $81 \%$ & June 2020 in India \\
\hline Sinovac (Corona-Vac) & Sinovac Biotech Chinese Company & 2 doses/2 weeks apart & $50.4-91 \%$ & July 2020 in China \\
\hline Sputnik V & $\begin{array}{l}\text { The Russia Ministry of Health's Gamaleya } \\
\text { Research Institute }\end{array}$ & 2 doses/3 weeks apart & $91.4 \%$ & August 2020 in Russia \\
\hline Sinopharm & $\begin{array}{l}\text { China National Pharmaceutical Group and the } \\
\text { Beijing Institute of Biological Products }\end{array}$ & 2 doses/3 weeks apart & $79 \%$ & Summer of 2020 in China \\
\hline Pfizer-BioNTech & $\begin{array}{l}\text { American company Pfizer and German biotechnol- } \\
\text { ogy company BioNTech }\end{array}$ & 2 doses/3 weeks apart & $95 \%$ & December 11,2020 in the USA \\
\hline Moderna & $\begin{array}{l}\text { Moderna Company and the National Institute of } \\
\text { Allergy \& Infectious diseases (NIAID) }\end{array}$ & 2 doses/4 weeks apart & $95 \%$ & December 18, 2020 in the USA \\
\hline Oxford-AstraZeneca & $\begin{array}{l}\text { Oxford University and pharmaceutical company } \\
\text { AstraZeneca }\end{array}$ & 2 doses/4 weeks apart & $70 \%$ & January 29,2021 in the UK \\
\hline Janssen & Johnson \& Johnson Company & 1 dose & $67-72 \%$ & February 25, 2021 in Bahrain \\
\hline
\end{tabular}


The COVID-19 pandemic has drawn the attention of investigators, scientists, and doctors to the links and interaction between infectious and non-communicable diseases. Consequently, it is crucial to investigate the relationship between viral infections and environmental factors (DomínguezAmarillo et al 2020).

\section{Air and COVID-19}

Before COVID-19, the world suffered from high levels of urban air pollution, primarily in the form of sulfur dioxide $\left(\mathrm{SO}_{2}\right)$, carbon dioxide $\left(\mathrm{CO}_{2}\right)$, nitrogen dioxide $\left(\mathrm{NO}_{2}\right)$, and particle matter (PM). The biggest causes of pollution are transportation, industry, and power plants, which are all responsible for the rising output of toxic pollutants (Arora et al 2020). Furthermore, over the previous decade, $\mathrm{CO}_{2}$ emissions increased by around $1 \%$ every year (Jackson et al 2019). According to WHO research, air pollution is responsible for over $8 \%$ of all deaths worldwide, and many respiratory disorders are already caused by it (WHO 2016). Various authorities worldwide have declared clean air programs to lower pollution levels for a long time (Arora et al 2020).

COVID-19 investigations in numerous countries, including the USA (Zambrano-Monserrate et al 2020), northern Italy (Liang et al 2020), and Europe (Conticini et al 2020), have found connections linking mortality and air pollution. Cole and colleagues discovered a link between air pollutant concentrations, with a special focus on $\mathrm{NO}_{2}$, and COVID-19 infectivity and mortality. A slight increase in air pollution is observed to result in a substantial rise in mortality rate and COVID-19 infectivity. For example, an increase of $1 \mathrm{~g} / \mathrm{m}^{3}$ in the long-term average of $\mathrm{PM}_{25}$ was linked to a 12 and $15 \%$ rise in COVID-19 cases in England (Cole et al 2020) and in the USA, respectively. In addition, nitrogen dioxide stands out as a very reactive pollutant generated mostly through the combustion of fossil fuels, with traffic pollution being the primary source (He et al 2020a, 2020b). It is linked to a $6.94 \%$ rise in daily COVID-19 confirmed case numbers in 120 Chinese cities (Copat et al 2020). A recent study found a relationship between high pollution levels in Italy with a special focus on Veneto, Lombardy, and Emilia-Romagna and COVID-19 mortality (Conticini et al 2020).

\section{Water and SARS-CoV-2}

The persistence and survival of human CoVs or surrogates in the laboratory were studied and demonstrated to be several days at $4{ }^{\circ} \mathrm{C}$ in the laboratory which is lower than nonenveloped viruses. In addition, this type of virus is heavily impacted by temperature, organic or microbial contamination, and other factors. They have only been discovered in a few field experiments, which could be attributable to the analytical methodologies' limited recovery effectiveness. Because there is so little information on human $\mathrm{CoV}$ in the environment, more studies are needed to understand how they behave in the water cycle (Carducci et al 2020). Some investigations demonstrated that the presence and survival of SARS-CoV-2 in wastewater is dependent on the parameters of this water (Carducci et al 2020). Surrogate coronaviruses are mentioned as being contagious in sewage and water for a few days to weeks (Casanova et al 2009). Barcelo 2020) reported that the half-life of SARS-CoV-2 in wastewater is between 4.8 and 7.2 h. Several field experiments in different countries concentrated on a SARS-CoV-2 search in water samples in the early months of 2020 , owing to an increased focus on the new coronavirus's environmental circulation. In these investigations, samples were collected for various types of water: hospital wastewater at different phases of the sodium hypochlorite disinfection process in China (Wang et al 2020a, b, c); raw and processed wastewater in France (Wurtzer et al 2020), in Italy (Rimoldi et al 2020), and in the USA, Massachusetts (Wu et al 2020a, b, c) and Montana (Nemudryi et al 2020); sewage samples in the Netherlands (Medema et al 2020) and in Australia (Ahmed et al 2020). The viral RNA in the collected samples was isolated, analyzed using RT-qPCR, and sequenced. The findings, on one hand, showed positive results for the presence of SARS-CoV-2 in waste, sewage, and untreated water with a very low concentration of viral genome. On the other hand, there was insignificant detection of SARSCoV-2 RNA in treated or processed water samples. In addition, VERO E6 cells were employed to test SARS-CoV-2 infectivity in water samples collected in Italy, which were measured daily using a reverse-phase light microscope to look for cytopathic effects (CPE). The findings showed that the virus is not able to infect these cells. More recently, from August 2020 to February 2021, Israel (Bar-Or et al 2021) collected nine wastewater samples from various locations, regions, and catchment populations once a month. SARSCoV-2 RNA was detected in the samples, which were analyzed and sequenced. Positive detection and penetration of the B.1.1.7 (UK) strain into Israel is expected in December 2020 , according to the findings.

\section{COVID-19 improved the environment conditions}

COVID-19 had a positive effect on the environment that allows us to say it is the biggest beneficiary from the pandemic. When SARS-CoV-2 spread rapidly in China, the authorities put the entire country on lockdown to control the transmission of the virus and relieve the strain on healthcare services (Wilder-Smith and Freedman 2020). They shut down public transportation, educational institutions, 
businesses, manufacturing plants, parks, and other social gathering places. By the end of March 2020, most countries were under some type of lockdown (Tosepu et al 2020). Government's regulations have both beneficial and negative indirect environmental consequences as discussed in the following sections.

\section{Pollution of the air}

The impact of the partial shutdown on global air pollution levels has been investigated. Several studies found a significant reduction in air pollution. In the last 30 days (March-April 2020), steps to restrict SARS-CoV-2 reduced the $\mathrm{NO}_{2}$ and PM levels by 40 and $10 \%$, respectively, and saved 11,000 deaths by air pollution, as reported by the Centre for Research on Energy and Clean Air (CREA) (Myllyvirta and Thieriot 2020). The city of Rio de Janeiro's air quality revealed considerable reductions in carbon monoxide (CO) levels (30.3-48.5\%) and $\mathrm{NO}_{2}$. $\mathrm{PM}_{10}$ (particulate matter with a diameter of $10 \mu \mathrm{m}$ ) levels were lowered in just the first week of the shutdown (Dantas et al 2020), compared to what was seen in China (Liu et al 2020), Italy (Conticini et al 2020), Spain (Tob'ias et al. 2020), and other parts of the world. Furthermore, the National Aeronautics and Space Administration (NASA) and the European Space Agency (ESA) acquired data using the AURA and Sentinel-5P satellites, respectively. Satellite photographs of some countries and cities around the world before and after the lockdown show that environmental quality has improved and that $\mathrm{NO}_{2}$ emissions have decreased by up to $30 \%$ because of COVID19 (Muhammad et al 2020). Daily worldwide $\mathrm{CO}_{2}$ emissions were 17\% lower in April 2020 than in April 2019, but levels rebounded once limits were lifted (Le Quéré et al 2020). According to a recent projection from the Worldwide Carbon Project, global $\mathrm{CO}_{2}$ emissions from fossil fuels and industry will decrease by 7\% during 2020 (Global Carbon Project 2020). Moreover, in Fortaleza, $\mathrm{O}_{3}$ levels in the air were reduced by 50\% (Report 21 2020). Four air quality testing stations in the city of São Paulo revealed significant reductions in $\mathrm{NO}, \mathrm{NO}_{2}$, and $\mathrm{CO}$ concentrations by $77.3 \%, 54.3 \%$, and $64.8 \%$, respectively, in respect to the 5-year monthly average (Nakada and Urban 2020).

\section{Beaches and rivers}

Seaside landforms or beaches are considered as one of the beautiful natural resource areas (Zambrano-Monserrate et al 2020). However, people's irresponsible behavior has resulted in pollution issues at numerous beaches across the world (Partelow et al 2015). The lack of people owing to the current coronavirus outbreak has altered the appearance of several beaches globally. These places appear cleaner and have clear crystal blue waters during the lockdown period. In addition, the surface water quality of some rivers like the Ganga river has significantly improved in recent months. After the lockdown, the industries were halted, and much of the industrial effluent that was dumped into these rivers was also stopped (Muduli et al 2021). In addition, because there was less untreated or partially treated wastewater injected, the aquatic bodies were less polluted (Ormaza-González et al 2021). It can be said that the world's oceans, rivers, and streams are once again becoming clear and alive during the shutdown period.

\section{Wildlife and the degree of noise}

Vehicles, trains and metro stations, commercial shipping, traffic noise, and industrials are all causes of noise pollution. COVID-19 also influenced noise pollution, which was found to be decreased by up to $40 \%$ during the lockdown period, and pollution generated by human activity was also dramatically reduced (Arora et al 2020). Moreover, animals were also provided locations that were normally occupied by humans and their activities, so many animals were seen around and in the spotlight during the coronavirus outbreak (Arora et al 2020).

\section{COVID-19's harmful effects on the environment}

The lockdown, on the other hand, has detrimental indirect effects on the environment. During the global lockdown, organic, inorganic, and medical wastes all increased. There has been a surge in garbage from personal protection equipment (PPE) such as masks and gloves, which are commonly required, particularly in large countries such as China and the USA (Adyel 2020). In addition, recycling, which is a popular and successful method of reducing pollution, conserving energy, and conserving natural resources (Ma et al 2019), has been restricted in some countries and cities globally. As a result of the epidemic, certain countries, such as the USA, restricted recycling activities in some of their cities, citing concerns about COVID-19 spreading through recycling facilities. Furthermore, waste management has been restricted in some of the worst-affected European countries (Staub 2020).

While there is evidence that environmental factors such as pollution and climate change may aid viral spread, further studies are needed to improve the detection and prevention methodology, systems, and tools for public health risk management (Travaglio et al. 2021). 


\section{Conclusion}

For the last 2 years (2019-2021), the global population has been suffering from COVID-19 created by the novel SARS$\mathrm{CoV}-2$. In this review, we summarized the relevant information about the new human coronavirus (SARS-CoN-2) which include the virus identity, where it spread for the first time, and how it can infect people. In addition, the diagnostic strategies that have been used or developed to detect the virus and its disease (COVID-19) are discussed. Scientists have developed new methods and techniques for detecting SARS-CoV-2 in its early stage of infection and to stop its transmission. The molecular diagnosis based on the viral genome and proteome is a more rapid, simple, and sensitive detection method. Moreover, nanotechnology technique was applied for creating highly effective and beneficial disinfection systems, developing sensors that can quickly detect SARS-CoV-2 and generating materials or particles to cross the cell membranes and target exclusive subcellular sites. There are several evidence from various countries around the world that confirmed, on one hand, the negative effect of environmental pollution on the spread and mortality of COVID-19, and, on the other hand, the positive impact of the lockdown due to the COVID-19 pandemic on environmental sources including air, water, and soil. A significant reduction in gaseous pollutants such as $\mathrm{CO}, \mathrm{CO}_{2}, \mathrm{NO}, \mathrm{NO}_{2}$, $\mathrm{SO}_{2}, \mathrm{PM}_{10}$, and $\mathrm{PM}_{2.5}$ produced through industrial production and traffic was reported in China, the USA, France, Italy, Spain, Brazil, and other countries in the globe, and an improvement in the water quality was also noticed. Furthermore, animals were also provided locations that were normally occupied by humans and their activities, so many animals were seen around and in the spotlight during the coronavirus outbreak. It has been found that COVID-19 also influenced noise pollution, which was dramatically reduced by up to $40 \%$ during the curfew. Finally, we can say that lockdown period was a great chance for the environment to reduce pollution and for the earth to start breathing again.

Although an enormous amount of research has been carried out into the pandemic, there are still requirements for more research and data analysis. Scientists have been working globally to develop new biotechnology methodologies to help find new diagnostic techniques, therapies, and vaccines against COVID-19. To reduce the possibility that the virus will mutate and cause more waves of infection, it is essential that clinicians can rapidly and accurately diagnose the presence of the virus, that vaccines should be fairly shared around the world, and that public health measures such as hand washing, social distancing, and wearing face masks should be maintained.

It is worth noting that COVID-19 data are constantly being updated as more research is published. Additional studies may change some of the specifics contained in this review. Furthermore, some manuscripts mentioned in references are preprints and have not yet been peer reviewed.

Acknowledgements The authors extend their appreciation to Taif University, College of Science, KSA for supporting this project. Also, the authors extend their appreciation to the University of Misan and University of Basrah, Iraq and Mahatma Gandhi University, India for their technical support.

Author contribution FA supervised the project and worked on all aspects of the manuscript in collaboration with authors. SA, MN, AA, and ST were involved in the writing, literature, data collection, and analysis of the manuscript. AA and ST reviewed, proofread, and edited the final draft of manuscript. FA and $\mathrm{MN}$ worked with figure preparation and software. SA analyzed and reviewed the final draft. All authors reviewed, contributed to the final manuscript, read, and approved the final draft.

Funding This research received no external funding.

Data availability All data generated or analyzed during this study are included in this published article.

\section{Declarations}

Competing interests The authors declare that they have no competing interests.

\section{References}

Adams MJ, Lefkowitz EJ, King AM, Harrach B, Harrison RL, Knowles NJ et al (2016) Ratification vote on taxonomic proposals to the International Committee on Taxonomy of Viruses. Adv Virol 161(10):2921-2949. https://doi.org/10. 1007/s00705-016-2977-6

Adedeji AO, Severson W, Jonsson C, Singh K, Weiss SR, Sarafianos SG (2013) Novel inhibitors of severe acute respiratory syndrome coronavirus entry that act by three distinct mechanisms. J Virol 87(14):8017-8028. https://doi.org/10.1128/JVI.00998-13

Adyel T (2020) Accumulation of plastic waste during COVID-19. Sci 369(6509):1314-1315. https://doi.org/10.1126/science.abd9925

Ahmed W, Angel N, Edson J, Bibby K, Bivins A, O'Brien JW et al (2020) First confirmed detection of SARS-CoV-2 in untreated wastewater in Australia: a proof of concept for the wastewater surveillance of COVID-19 in the community. Sci Total Environ 728:138764. https://doi.org/10.1016/j.scitotenv.2020.138764

Anderson RM, Heesterbeek H, Klinkenberg D, Hollingsworth TD (2020) How will country-based mitigation measures influence the course of the COVID-19 epidemic? Lancet (london, England) 395(10228):931-934. https://doi.org/10.1016/S0140-6736(20) $30567-5$

Antiochia R (2021) Paper-based biosensors: frontiers in point-of-care detection of COVID-19 disease. Biosensors 11(4):110. https:// doi.org/10.3390/bios11040110

Apolone G, Montomoli E, Manenti A, Boeri M, Sabia F, Hyseni I, et al (2020) Unexpected detection of SARS-CoV-2 antibodies in the prepandemic period in Italy. Tumori, 300891620974755. Advance online publication. https://doi.org/10.1177/0300891620 974755 
Arora S, Bhaukhandi KD, Mishra PK (2020) Coronavirus lockdown helped the environment to bounce back. Sci Total Environ 742:140573. https://doi.org/10.1016/j.scitotenv.2020.140573

Asrani P, Hasan GM, Sohal SS, Hassan MI (2020) Molecular basis of pathogenesis of coronaviruses: a comparative genomics approach to planetary health to prevent zoonotic outbreaks in the 21 st century. OMICS J Integr Biol 24(11):634-644. https://doi.org/10. 1089/omi.2020.0131

Aynaud MM, Hernandez JJ, Barutcu S, Braunschweig U, Chan $\mathrm{K}$, Pearson JD et al (2021) A multiplexed, next generation sequencing platform for high-throughput detection of SARSCoV-2. Nat Commun 12(1):1405. https://doi.org/10.1038/ s41467-021-21653-y

Bai Y, Yao L, Wei T, Tian F, Jin DY, Chen L, Wang M (2020) Presumed asymptomatic carrier transmission of COVID-19. JAMA 323(14):1406-1407. https://doi.org/10.1001/jama.2020.2565

Barcelo D (2020) An environmental and health perspective for COVID19 outbreak: meteorology and air quality influence, sewage epidemiology indicator, hospitals disinfection, drug therapies and recommendations. J Environ Chem Eng 8(4):104006. https://doi. org/10.1016/j.jece.2020.104006

Bar-Or I, Weil M, Indenbaum V, Bucris E, Bar-Ilan D, Elul M et al (2021) Detection of SARS-CoV-2 variants by genomic analysis of wastewater samples in Israel. Sci total environ 789:148002. https://doi.org/10.1016/j.scitotenv.2021.148002 (Advance online publication)

Basak S, Packirisamy G (2020) Nano-based antiviral coatings to combat viral infections. Nanostruct Nanoobjects 24:100620. https:// doi.org/10.1016/j.nanoso.2020.100620

Bosch BJ, van der Zee R, de Haan CA, Rottier PJ (2003) The coronavirus spike protein is a class I virus fusion protein: structural and functional characterization of the fusion core complex. J Virol 77(16):8801-8811. https://doi.org/10.1128/jvi.77.16.8801-8811. 2003

Braun J, Loyal L, Frentsch M, Wendisch D, Georg P, Kurth F et al (2020) SARS-CoV-2-reactive T cells in healthy donors and patients with COVID-19. Nature 587(7833):270-274. https:// doi.org/10.1038/s41586-020-2598-9

Brazilchuck N (2020) From thousands of tiny magnetic balls to 150,000 COVID-19 tests per week. Norwegian SciTech News. https:// norwegianscitechnews.com/2020/04/from-thousands-of-tinymagnetic-balls-to-150000-covid-19-tests-per-week/. (Accessed 22 Oct 2021)

Broughton JP, Deng X, Yu G, Fasching CL, Servellita V, Singh J et al. (2020) CRISPR-Cas12-based detection of SARS-CoV-2. Nat Biotechnol 38, 870-874 https://www.nature.com/articles/ s41587-020-0513-4

Campos EVR, Pereira AES, de Oliveira JL, Carvalho LB, GuilgerCasagrande M, de Lima R, Fraceto LF (2020) How can nanotechnology help to combat COVID-19? Opportunities and Urgent Need. J Nanobiotechnol 18:125. https://doi.org/10.1186/ s12951-020-00685-4

Canard B, Joseph JS, Kuhn P (2008) International research networks in viral structural proteomics: again, lessons from SARS. Antiviral Res 78(1):47-50. https://doi.org/10.1016/j.antiviral.2007.09.007

Cantuti-Castelvetri L, Ojha R, Pedro LD, Djannatian M, Franz J, Kuivanen $S$ et al (2020) Neuropilin-1 facilitates SARS-CoV-2 cell entry and infectivity. Sci (New York, N.Y.) 370(6518):856-860. https://doi.org/10.1126/science.abd2985

Carducci A, Federigi I, Liu D, Thompson JR, Varni M (2020) Making waves: coronavirus detection, persistence and persistence in the water environment: state of the art and knowledge needs for public health. Water Res 179:115907. https://doi.org/10.1016/j. watres.2020.115907

Carrat F, Figoni J, Henny J, Desenclos JC, Kab S, de Lamballerie X, Zins M (2021) Evidence of early circulation of SARS-CoV-2 in
France: findings from the population-based "CONSTANCES" cohort. Eur J Epidemiol 36(2):219-222. https://doi.org/10. 1007/s10654-020-00716-2

Carter LJ, Garner LV, Smoot JW, Li Y, Zhou Q, Saveson CJ et al (2020) Assay techniques and test development for COVID19 diagnosis. ACS Cent Sci 6(5):591-605. https://doi.org/10. 1021/acscentsci.0c00501

Caruana G, Croxatto A, Coste AT, Opota O, Lamoth F, Jaton K, Greub G (2020) Diagnostic strategies for SARS-CoV-2 infection and interpretation of microbiological results. Clin Microbiol Infect Off Publ Eur Soc Clin Microbiol Infect Dis 26(9):1178-1182. https://doi.org/10.1016/j.cmi.2020.06.019

Casanova L, Rutala WA, Weber DJ, Sobsey MD (2009) Survival of surrogate coronaviruses in water. Water Res 43(7):1893-1898. https://doi.org/10.1016/j.watres.2009.02.002

Chan JF, Yip CC, To KK, Tang TH, Wong SC, Leung KH et al (2020) Improved molecular diagnosis of COVID-19 by the novel, highly sensitive and specific COVID-19-RdRp/Hel realtime reverse transcription-PCR assay validated in vitro and with clinical specimens. J Clin Microbiol 58(5):e00310-e320. https://doi.org/10.1128/JCM.00310-20

Chan-Yeung M, Xu RH (2003) SARS: epidemiology. Respirology (Carlton Vic) 8 Suppl(Suppl 1):S9-S14. https://doi.org/10. 1046/j.1440-1843.2003.00518.x

Chen Y, Rajashankar KR, Yang Y, Agnihothram SS, Liu C, Lin YL, Baric RS, Li F (2013) Crystal structure of the receptor-binding domain from newly emerged Middle East respiratory syndrome coronavirus. J Virol 87(19):10777-10783. https://doi.org/10. 1128/JVI.01756-13

Cheng J, Zhao Y, Xu G, Zhang K, Jia W, Sun Y, Zhao J, Xue J, Hu Y, Zhang G (2019) The S2 subunit of QX-type infectious bronchitis coronavirus spike protein is an essential determinant of neurotropism. Viruses 11(10):972. https://doi.org/10.3390/ v11100972

Chiu CY (2013) Viral pathogen discovery. Curr Opin Microbiol 16(4):468-478. https://doi.org/10.1016/j.mib.2013.05.001

Cole MA, Ozgen C, Strobl E (2020) Air pollution exposure and Covid-19 in Dutch municipalities. Environ and res econ 1-30. Advance online publication. https://doi.org/10.1007/ s10640-020-00491-4.

Consortium CSME (2004) Molecular evolution of the SARS coronavirus during the course of the SARS epidemic in China. Sci (New York, N.Y.) 303(5664):1666-1669. https://doi.org/10. 1126/science.1092002

Conticini E, Frediani B, Caro D (2020) Can atmospheric pollution be considered a co-factor in extremely high level of SARSCoV-2 lethality in Northern Italy? Environ poll (Barking, Essex: 1987) 261:114465. https://doi.org/10.1016/j.envpol. 2020.114465

Copat C, Cristaldi A, Fiore M, Grasso A, Zuccarello P, Signorelli SS et al (2020) The role of air pollution (PM and NO2) in COVID-19 spread and lethality: a systematic review. Environ Res 191:110129. https://doi.org/10.1016/j.envres.2020.110129

Corman VM, Landt O, Kaiser M, Molenkamp R, Meijer A, Chu DK et al (2020) Detection of 2019 novel coronavirus (2019-nCoV) by real-time RT-PCR. Euro surveill bull Euro sur les mal transmissibles Euro commun dis bull 25(3):2000045. https://doi.org/ 10.2807/1560-7917.ES.2020.25.3.2000045

Coté JJ, Haggstrom J, Vivekanandan R, Coté KA, Real DL, Weber DP et al (2020) COVID 19 and a novel initiative to improve safety by $3 \mathrm{D}$ printing personal protective equipment parts from computed tomography. 3D print med 6(1):20. https://doi.org/10. 1186/s41205-020-00073-6

Cui J, Li F, Shi ZL (2019) Origin and evolution of pathogenic coronaviruses. Nat Rev Microbiol 17(3):181-192. https://doi.org/10. 1038/s41579-018-0118-9 
Cyranoski D (2020) Profile of a killer: the complex biology powering the coronavirus pandemic. Nature 581(7806):22-26. https://doi. org/10.1038/d41586-020-01315-7

Dancer SJ (2014) Controlling hospital-acquired infection: focus on the role of the environment and new technologies for decontamination. Clin Microbiol Rev 27(4):665-690. https://doi.org/10.1128/ CMR.00020-14

Dantas G, Siciliano B, Boscaro Franc AB, da Silva CM, Arbilla A (2020) The impact of COVID-19 partial lockdown on the air quality of the city of Rio. Sci Total Environ 729:139085. https:// doi.org/10.1016/j.scitotenv.2020.13908510.1016/j.scitotenv. 2020.139085

De Clercq E, Li G (2016) Approved antiviral drugs over the past 50 years. Clin Microbiol Rev 29(3):695-747. https://doi.org/10. 1128/CMR.00102-15

Deng X, Garcia-Knight MA, Khalid MM, Servellita V, Wang C, Morris MK et al (2021) Transmission, infectivity, and antibody neutralization of an emerging SARS-CoV-2 variant in California carrying a L452R spike protein mutation. MedRxiv Prepr Server Health Sci 03(07):21252647. https://doi.org/10.1101/2021.03. 07.21252647

Ding X, Yin K, Li Z, Liu C (2020) All-in-one dual CRISPR-Cas12a (AIOD-CRISPR) assay: a case for rapid, ultrasensitive and visual detection of novel coronavirus SARS-CoV-2 and HIV virus. BioRxiv : Prepr Serv Biol 03(19):998724. https://doi.org/10. 1101/2020.03.19.998724

Djomkam A, Olwal CO, Sala TB, Paemka L (2020) Commentary: SARS-CoV-2 cell entry depends on ACE2 and TMPRSS2 and is blocked by a clinically proven protease inhibitor. Front oncol 10:1448. https://doi.org/10.3389/fonc.2020.01448

Domínguez-Amarillo S, Fernández-Agüera J, Cesteros-García S, González-Lezcano RA (2020) Bad air can also kill: residential indoor air quality and pollutant exposure risk during the COVID19 crisis. Int J Environ Res Public Health 17(19):7183. https:// doi.org/10.3390/ijerph17197183

Dong X, Cao YY, Lu XX, Zhang JJ, Du H, Yan YQ, Akdis CA, Gao YD (2020) Eleven faces of coronavirus disease 2019. Allergy 75(7):1699-1709. https://doi.org/10.1111/all.14289

Draz MS, Shafiee H (2018) Applications of gold nanoparticles in virus detection. Theranostics 8(7):1985-2017. https://doi.org/10.7150/ thno.23856

Du L, He Y, Zhou Y, Liu S, Zheng BJ, Jiang S (2009) The spike protein of SARS-CoV-a target for vaccine and therapeutic development. Nat Rev Microbiol 7(3):226-236. https://doi.org/10.1038/ nrmicro2090

Dyshlyuk L, Babich O, Ivanova S, Vasilchenco N, Prosekov A, Sukhikh S (2020) Suspensions of metal nanoparticles as a basis for protection of internal surfaces of building structures from biodegradation. Case Stud Constr Mater 12:e00319. https://doi.org/ 10.1016/j.cscm.2019.e00319

Esbjörner EK, Lincoln P, Nordén B (2007) Counterion-mediated membrane penetration: cationic cell-penetrating peptides overcome Born energy barrier by ion-pairing with phospholipids. Biochem Biophys Acta 1768(6):1550-1558. https://doi.org/10.1016/j. bbamem.2007.03.004

Esparza TJ, Martin NP, Anderson GP, Goldman ER, Brody DL (2020) High affinity nanobodies block SARS-CoV-2 spike receptor binding domain interaction with human angiotensin converting enzyme. Sci Rep 10(1):22370. https://doi.org/10.1038/ s41598-020-79036-0

Eurosurveillance editorial team (2020) Note from the editors novel coronavirus (2019 nCoV). Euro Surveillance Bullet Eur Sur Les Maladies Trans Eur Commu Dis Bullet 25(3):2001231. https:// doi.org/10.2807/1560-7917.ES.2020.25.3.2001231

Falzarano D, de Wit E, Rasmussen AL, Feldmann F, Okumura A, Scott DP et al (2013) Treatment with interferon- $\alpha 2 b$ and ribavirin improves outcome in MERS-CoV-infected rhesus macaques. Nat Med 19(10):1313-1317. https://doi.org/10. 1038/nm.3362

Faria NR, Mellan TA, Whittaker C, Claro IM, Candido D, Mishra S et al (2021) Genomics and epidemiology of a novel SARS-CoV-2 lineage in Manaus. Brazil medRxiv the preprint server for health sciences 02(26):21252554. https://doi.org/10.1101/2021.02.26. 21252554

Feng W, Newbigging A, Le C, Pang B, Peng H, Cao Y et al (2020) Molecular diagnosis of COVID-19: challenges and research needs. Anal Chem 92:10196-10209. https://doi.org/10.1021/ acs.analchem.0c02060

FIND (2020) SARS-CoV-2 Diagnostic Pipeline [Internet]. Available from: https://www.finddx.org/covid-19/pipeline/. Accessed 22 Oct 2021

Fontanet A, Autran B, Lina B, Kieny MP, Karim S, Sridhar D (2021) SARS-CoV-2 variants and ending the COVID-19 pandemic. Lancet (london, England) 397(10278):952-954. https://doi.org/10. 1016/S0140-6736(21)00370-6

Fozouni P, Son S, de León Derby MD, Knott GJ, Gray CN, Dambrosio MV et al (2020) Direct detection of SARSCoV2 using CRISPR-Cas13a and a mobile phone. Infect Dis (except HIV/ AIDS). https://doi.org/10.1016/j.cell.2020.12.001

Gao J, Tian Z, Yang X (2020) Breakthrough: Chloroquine phosphate has shown apparent efficacy in treatment of COVID-19 associated pneumonia in clinical studies. Biosci Trends 14(1):72-73. https://doi.org/10.5582/bst.2020.01047

Geyer F, Dacunzi M, Sharifi-Aghili A, Saal A, Gao N, Kaltbeitzel A et al (2020) When and how self-cleaning of superhydrophobic surfaces works. Sci Adv 6(3):eaaw9727. https://doi.org/10.1126/ sciadv.aaw9727

Global Carbon Project (2020) Coronavirus causes 'record fall' in fossil-fuel emissions in 2020. https://www.carbonbrief.org/ global-carbon-projectcoronavirus- causes-record-fall-in-fossilfuelemissions-in-2020. (Accessed 22 Oct 2021).

Gootenberg JS, Abudayyeh OO, Lee JW, Essletzbichler P, Dy AJ, Joung J et al (2017) Nucleic acid detection with CRISPR-Cas13a/ C2c2. Science 356(6336):438-442. https://doi.org/10.1126/scien ce.aam9321

Gorbalenya A, Baker S, Baric R, de Groot R, Drosten C, Gulyaeva A et al (2020) The species severe acute respiratory syndrome related coronavirus: classifying $2019-\mathrm{nCoV}$ and naming it SARS-CoV-2. Nat Microbiol 5:536-544. https://doi.org/10.1038/ s41564-020-0695-Z

Grifoni A, Weiskopf D, Ramirez SI, Mateus J, Dan JM, Moderbacher CR et al (2020) Targets of T cell responses to SARS-CoV-2 coronavirus in humans with COVID-19 disease and unexposed individuals. Cell 181(7):1489-1501.e15. https://doi.org/10.1016/j. cell.2020.05.015

Guan WJ, Ni ZY, Hu Y, Liang WH, Ou CQ, He JX et al (2020) Clinical characteristics of coronavirus disease 2019 in China. N Engl J Med 382(18):1708-1720. https://doi.org/10.1056/NEJMoa2002 032

Guo T, Fan Y, Chen M, Wu X, Zhang L, He T, Wang H, Wan J, Wang X, Lu Z (2020) Cardiovascular implications of fatal outcomes of patients with coronavirus disease 2019 (COVID-19). JAMA Cardiology 5(7):811-818. https://doi.org/10.1001/jamacardio. 2020.1017

Gupta R, Kazi TA, Dey D, Ghosh A, Ravichandiran V, Swarnakar $\mathrm{S}$ et al (2021) CRISPR detectives against SARS-CoV-2: a major setback against COVID-19 blowout. Appl Microbiol Biotechnol 105(20):7593-7605. https://doi.org/10.1007/ s00253-021-11583-6

Halfpenny KC, Wright DW (2010) Nanoparticle detection of respiratory infection. Wiley Interdiscip Rev Nanomed Nanobiotechnol 2(3):277-290. https://doi.org/10.1002/wnan.83 
He MZ, Kinney PL, Li T, Chen C, Sun Q, Ban J et al (2020) Shortand intermediate-term exposure to $\mathrm{NO} 2$ and mortality: a multicounty analysis in China. Environ Pollut. https://doi.org/10. 1016/j.envpol.2020.114165

He L, Zhang S, Hu J, Li Z, Zheng X, Cao Y et al (2020) On-road emission measurements of reactive nitrogen compounds from heavy-duty diesel trucks in China. Environ Pollut. https://doi. org/10.1016/j.envpol.2020.114280

Henrich S, Cameron A, Bourenkov GP, Kiefersauer R, Huber R, Lindberg I, Bode W, Than ME (2003) The crystal structure of the proprotein processing proteinase furin explains its stringent specificity. Nat Struct Biol 10(7):520-526. https://doi.org/10. 1038/nsb941

Hilgenfeld R, Peiris M (2013) From SARS to MERS: 10 years of research on highly pathogenic human coronaviruses. Antiviral Res 100(1):286-295. https://doi.org/10.1016/j.antiviral.2013. 08.015

Hodcroft EB, Domman DB, Snyder DJ, Oguntuyo KY, Van Diest M, Densmore KH et al (2021) Emergence in late 2020 of multiple lineages of SARS-CoV-2 Spike protein variants affecting amino acid position 677 . MedRxiv the preprint server for health sciences 02(12):21251658. https://doi.org/10.1101/2021.02.12. 21251658

Hoffmann M, Kleine-Weber H, Schroeder S, Krüger N, Herrler T, Erichsen S et al (2020) SARS-CoV-2 cell entry depends on ACE2 and TMPRSS 2 and is blocked by a clinically proven protease inhibitor. Cell 181(2):271-280.e8. https://doi.org/10.1016/j. cell.2020.02.052

Holland LA, Kaelin EA, Maqsood R, Estifanos B, Wu LI, Varsani A, Halden RU, Hogue BG, Scotch M, Lim ES (2020) An 81-nucleotide deletion in SARS-CoV-2 ORF7a identified from sentinel surveillance in Arizona (January to March 2020). J Virol 94(14):e00711-e720. https://doi.org/10.1128/JVI.00711-20

Holshue ML, DeBolt C, Lindquist S, Lofy KH, Wiesman J, Bruce H et al (2020) First case of 2019 novel coronavirus in the United States. N Engl J Med 382(10):929-936. https://doi.org/10.1056/ NEJMoa2001191

Hou T., Zeng W., Yang M., Chen W., Ren L., Ai J., et al. (2020). Development and evaluation of a rapid CRISPR-based diagnostic for COVID-19. Edited by Florian Krammer. PloS Pathog. 16 (8), e1008705. doi: 10.1371/ journal.ppat.1008705 https://covid19. who.int/ (Accessed 8th Aug 2021). https://www.who.int/newsroom/feature-stories/detail/the-race-for-a-covid-19-vaccine-expla ined. (Accessed 8th Aug 2021).

Huang Q, Yu L, Petros AM, Gunasekera A, Liu Z, Xu N, Hajduk P, Mack J, Fesik SW, Olejniczak ET (2004) Structure of the N-terminal RNA-binding domain of the SARS CoV nucleocapsid protein. Biochemistry 43(20):6059-6063. https://doi.org/10. 1021/bi036155b

Huang C, Wang Y, Li X, Ren L, Zhao J, Hu Y et al (2020) Clinical features of patients infected with 2019 novel coronavirus in Wuhan, China. Lancet (london, England) 395(10223):497-506. https:// doi.org/10.1016/S0140-6736(20)30183-5

Huang Z, Tian D, Liu Y, Lin Z, Lyon CJ, Lai W et al (2020) Ultrasensitive and high-throughput CRISPR-powered COVID-19 diagnosis. Biosens Bioelectron 164:112316. https://doi.org/10. 1016/j.bios.2020.112316

Ishige T, Murata S, Taniguchi T, Miyabe A, Kitamura K, Kawasaki $\mathrm{K}$ et al (2020) Highly sensitive detection of SARS-CoV-2 RNA by multiplex rRT-PCR for molecular diagnosis of COVID-19 by clinical laboratories. Clin Chimica Acta Int J Clin Chem 507:139-142. https://doi.org/10.1016/j.cca.2020.04.023

Islam KU, Iqbal J (2020) An update on molecular diagnostics for COVID-19. Front Cell Infect Microbiol 10:560616. https://doi. org/10.3389/fcimb.2020.560616
Islam MR, Hoque MN, Rahman MS, Alam A, Akther M, Puspo JA, Akter S, Sultana M, Crandall KA, Hossain MA (2020) Genomewide analysis of SARS-CoV-2 virus strains circulating worldwide implicates heterogeneity. Sci Rep 10(1):14004. https://doi. org/10.1038/s41598-020-70812-6

Izaguirre G (2019) The proteolytic regulation of virus cell entry by furin and other proprotein convertases. Viruses 11(9):837. https://doi.org/10.3390/v11090837

Jackson RB, Friedlingstein P, Andrew RM, Canadell JG, LeQuere C, Peters GP (2019) Persistent fossil fuel growth threatens the Paris Agreement and planetary health. Environ Res LetT 14:121001. https://doi.org/10.1088/1748-9326/ab57b3

Jackson LA, Anderson EJ, Rouphael NG, Roberts PC, Makhene M, Coler RN et al (2020) An mRNA vaccine against SARS-CoV-2 - preliminary report. N Engl J Med 383(20):1920-1931. https:// doi.org/10.1056/NEJMoa2022483

Jiang HW, Li Y, Zhang HN, Wang W, Yang X, Qi H et al (2020) SARSCoV-2 proteome microarray for global profiling of COVID-19 specific IgG and IgM responses. Nat Commun 11:3581. https:// doi.org/10.1038/s41467-020-17488-8

Ju B, Zhang Q, Ge J, Wang R, Sun J, Ge X et al (2020) Human neutralizing antibodies elicited by SARS-CoV-2 infection. Nature 584(7819):115-119. https://doi.org/10.1038/s41586-020-2380-z

Karim N, Afroj S, Lloyd K, Oaten LC, Andreeva DV, Carr C, Farmery AD, Kim ID, Novoselov KS (2020) Sustainable personal protective clothing for healthcare applications: a review. ACS Nano 14(10):12313-12340. https://doi.org/10.1021/acsnano.0c05537

Kirola L. (2021). Genetic emergence of B.1.617.2 in COVID-19. New microbes and new infections, 100929. Advance online publication. https://doi.org/10.1016/j.nmni.2021.100929

Korber B, Fischer WM, Gnanakaran S, Yoon H, Theiler J, Abfalterer $\mathrm{W}$ et al (2020) Tracking changes in SARS-CoV-2 spike: evidence that D614G increases infectivity of the COVID-19 virus. Cell 182(4):812-827.e19. https://doi.org/10.1016/j.cell.2020.06.043

Lan J, Ge J, Yu J, Shan S, Zhou H, Fan S, Zhang Q, Shi X, Wang Q, Zhang L, Wang X (2020) Structure of the SARS-CoV-2 spike receptor-binding domain bound to the ACE2 receptor. Nature 581(7807):215-220. https://doi.org/10.1038/s41586-020-2180-5

Lau SK, Woo PC, Li KS, Huang Y, Tsoi HW, Wong BH, Wong SS, Leung SY, Chan KH, Yuen KY (2005) Severe acute respiratory syndrome coronavirus-like virus in Chinese horseshoe bats. Proc Natl Acad Sci USA 102(39):14040-14045. https://doi.org/10. 1073/pnas.0506735102

Lau SK, Feng Y, Chen H, Luk HK, Yang WH, Li KS et al (2015) Severe acute respiratory syndrome (SARS) coronavirus ORF8 protein is acquired from SARS-related coronavirus from greater horseshoe bats through recombination. J Virol 89(20):1053210547. https://doi.org/10.1128/JVI.01048-15

Le Bert N, Tan AT, Kunasegaran K, Tham CYL, Hafezi M, Chia A et al (2020) SARS-CoV-2-specific T cell immunity in cases of COVID-19 and SARS, and uninfected controls. Nature 584:457462. https://doi.org/10.1038/s41586-020-2550-Z

Le Quéré C, Jackson RB, Jones MW, Smith AJP, Abernethy S, Andrew $\mathrm{RM}$ et al (2020) Temporary reduction in daily global CO2 emissions during the COVID-19 forced confinement. Nat Clim Chang 10:647-653. https://doi.org/10.1038/s41558-020-0797-x

Lembo D, Donalisio M, Civra A, Argenziano M, Cavalli R (2018) Nanomedicine formulations for the delivery of antiviral drugs: a promising solution for the treatment of viral infections. Expert Opin Drug Deliv 15(1):93-114. https://doi.org/10.1080/17425 247.2017.1360863

Li W, Moore MJ, Vasilieva N, Sui J, Wong SK, Berne MA et al (2003) Angiotensin-converting enzyme 2 is a functional receptor for the SARS coronavirus. Nature 426(6965):450-454. https://doi.org/ 10.1038/nature02145 
Li F, Li W, Farzan M, Harrison SC (2005) Structure of SARS coronavirus spike receptor-binding domain complexed with receptor. Sci (New York NY) 309(5742):1864-1868. https://doi.org/10. 1126/science. 1116480

Li JY, Liao CH, Wang Q, Tan YJ, Luo R, Qiu Y, Ge XY (2020) The ORF6, ORF8 and nucleocapsid proteins of SARS-CoV-2 inhibit type I interferon signaling pathway. Virus Res 286:198074. https://doi.org/10.1016/j.virusres.2020.198074

Li Q, Wu J, Nie J, Zhang L, Hao H, Liu S et al (2020) The impact of mutations in SARS-CoV-2 spike on viral infectivity and antigenicity. Cell 182(5):1284-1294.e9. https://doi.org/10.1016/j. cell.2020.07.012

Liang D, Shi L, Zhao J, Liu P, Sarnat JA, Gao S et al (2020) Urban air pollution may enhance COVID-19 case-fatality and mortality rates in the United States. Innovation (New York NY) 1(3):100047. https://doi.org/10.1016/j.xinn.2020.100047

Lin CW, Lin KH, Hsieh TH, Shiu SY, Li JY (2006) Severe acute respiratory syndrome coronavirus 3C-like protease-induced apoptosis. FEMS Immunol Med Microbiol 46(3):375-380. https://doi.org/ 10.1111/j.1574-695X.2006.00045.X

Liu J, Zhou J, Jinxi YJ, Zhang X, Li L, Xu X (2020) Impact of meteorological factors on the COVID-19 transmission: a multi-city study in China. Sci Total Environ 726:138513. https://doi.org/ 10.1016/j.scitotenv.2020.138513

Loeffelholz MJ, Tang YW (2020) Laboratory diagnosis of emerging human coronavirus infections - the state of the art. Emerg Microbes Infect 9(1):747-756. https://doi.org/10.1080/22221 751.2020 .1745095

Ma B, Li X, Jiang Z, Jiang J (2019) Recycle more, waste more? When recycling efforts increase resource consumption. J Clean Prod 206:870-877. https://doi.org/10.1016/j.jclepro.2018.09.063

Malik YA (2020) Properties of coronavirus and SARS-CoV-2. Malays J Pathol 42(1):3-11

Manfredonia I, Nithin C, Ponce-Salvatierra A, Ghosh P, Wirecki TK, Marinus $\mathrm{T}$ et al (2020) Genome-wide mapping of SARS-CoV-2 RNA structures identifies therapeutically-relevant elements. Nucleic Acids Res 48(22):12436-12452. https://doi.org/10.1093/ nar/gkaa1053

Mansi A, Boccuni F, Iavicoli S (2019) Nanomaterials as a new opportunity for protecting workers from biological risk. Ind Health 57(6):668-675. https://doi.org/10.2486/indhealth.2018-0197

Masters PS (2019) Coronavirus genomic RNA packaging. Virol 537:198-207. https://doi.org/10.1016/j.virol.2019.08.031

Meckiff BJ, Ramírez-Suástegui C, Fajardo V, Chee SJ, Kusnadi A, Simon $\mathrm{H}$ et al (2020) Imbalance of regulatory and cytotoxic SARS-CoV-2-reactive CD4 ${ }^{+} \mathrm{T}$ cells in COVID-19. Cell 183(5):1340-1353.e16. https://doi.org/10.1016/j.cell.2020.10. 001

Medema G, Been F, Heijnen L, Petterson S (2020) Implementation of environmental surveillance for SARS-CoV-2 virus to support public health decisions: opportunities and challenges. Curr Opin Environ Sci Health 17:49-71. https://doi.org/10.1016/j.coesh. 2020.09.006

Millet JK, Whittaker GR (2014) Host cell entry of Middle East respiratory syndrome coronavirus after two-step, furin-mediated activation of the spike protein. Proc Natl Acad Sci USA 111(42):15214-15219. https://doi.org/10.1073/pnas.1407087111

Moitra P, Alafeef M, Dighe K, Frieman MB, Pan D (2020) Selective naked-eye detection of SARS-CoV-2 mediated by N gene targeted antisense oligonucleotide capped plasmonic nanoparticles. ACS Nano 14(6):7617-7627. https://doi.org/10.1021/acsnano. 0c03822

Moon JJ, Suh H, Polhemus ME, Ockenhouse CF, Yadava A, Irvine DJ (2012) Antigen-displaying lipid-enveloped PLGA nanoparticles as delivery agents for a Plasmodium vivax malaria vaccine. PLoS ONE 7(2):e31472. https://doi.org/10.1371/journal.pone.0031472
Muduli PR, Kumar A, Kanuri VV, Mishra DR, Acharya P, Saha R et al (2021) Water quality assessment of the Ganges River during COVID-19 lockdown. Int J Environ Sci Technol 18:16451652. https://doi.org/10.1007/s13762-021-03245-x

Muhammad S, Long X, Salman M (2020) COVID-19 pandemic and environmental pollution: a blessing in disguise? Sci Total Environ 728:138820. https://doi.org/10.1016/j.scitotenv.2020. 138820

Murugan D., Bhatia H., Sai V., Satija J. (2020). P-FAB: a fiber-optic biosensor device for rapid detection of COVID-19. Trans Indian National Acad Eng, 1-5. Advance online publication. https://doi. org/10.1007/s41403-020-00122-w.

Muth D, Corman VM, Roth H, Binger T, Dijkman R, Gottula LT et al (2018) Attenuation of replication by a 29-nucleotide deletion in SARS-coronavirus acquired during the early stages of humanto-human transmission. Sci Rep 8(1):15177. https://doi.org/10. 1038/s41598-018-33487-8

Myllyvirta L., Thieriot H. (2020). 11.000 air pollution-related deaths avoided in Europe as coal, oil consumption plummet. Available in: https://energyandcleanair.org/wp/wp-content/uploads/2020/ 04/CREA-Europe-COVID-impacts.pdf. (Accessed 22 Oct 2021).

Nag, P., Sadani, K., Mukherji, S. (2020). Optical fiber sensors for rapid screening of COVID-19. Transactions of the Indian National Academy of Engineering, 1-4. Advance online publication. https://doi.org/10.1007/s41403-020-00128-4.

Nakada L, Urban RC (2020) COVID-19 pandemic: impacts on the air quality during the partial lockdown in São Paulo state, Brazil. Sci Total Environ 730:139087. https://doi.org/10.1016/j.scito tenv.2020.139087

Nelson CW, Ardern Z, Goldberg TL, Meng C, Kuo CH, Ludwig C, Kolokotronis SO, Wei X (2020) Dynamically evolving novel overlapping gene as a factor in the SARS-CoV-2 pandemic. ELife 9:e59633. https://doi.org/10.7554/eLife.59633

Nemudryi A, Nemudraia A, Wiegand T, Surya K, Buyukyoruk M, Cicha $C$ et al (2020) Temporal detection and phylogenetic assessment of SARS-CoV-2 in municipal wastewater. Cell Reports Medicine 1(6):100098. https://doi.org/10.1016/j.xcrm.2020. 100098

Oostra M, de Haan CA, Rottier PJ (2007) The 29-nucleotide deletion present in human but not in animal severe acute respiratory syndrome coronaviruses disrupts the functional expression of open reading frame 8. J Virol 81(24):13876-13888. https://doi.org/ 10.1128/JVI.01631-07

Ormaza-González FI, Castro-Rodas D, Statham PJ (2021) COVID-19 impacts beaches and coastal water pollution at selected sites in Ecuador, and management proposals post-pandemic. Front Mar Sci 8:669374. https://doi.org/10.3389/fmars.2021.669374

Ou J, Zhou Z, Dai R, Zhang J, Zhao S, Wu X, Lan W et al (2021) V367F mutation in SARS-CoV-2 spike RBD emerging during the early transmission phase enhances viral infectivity through increased human ACE2 receptor binding affinity. J Virol 95(16):e0061721. https://doi.org/10.1128/JVI.00617-21

Paraskevis D, Kostaki EG, Magiorkinis G, Panayiotakopoulos G, Sourvinos G, Tsiodras S (2020) Full-genome evolutionary analysis of the novel corona virus (2019-nCoV) rejects the hypothesis of emergence as a result of a recent recombination event. Infect, Gene Evol : J Mole Epidemiol Evol Gene Infect Dis 79:104212. https://doi.org/10.1016/j.meegid.2020.104212

Partelow S, von Wehrden H, Horn O (2015) Pollution exposure on marine protected areas: a global assessment. Mar Pollut Bull 100:352-358. https://doi.org/10.1016/j.marpolbul.2015.08.026

Pollán M, Pérez-Gómez B, Pastor-Barriuso R, Oteo J, Hernán MA, Pérez-Olmeda $\mathrm{M}$ et al (2020) Prevalence of SARS-CoV-2 in Spain (ENE-COVID): a nationwide, population-based seroepidemiological study. Lancet (london, England) 396(10250):535544. https://doi.org/10.1016/S0140-6736(20)31483-5 
Querido MM, Aguiar L, Neves P, Pereira CC, Teixeira JP (2019) Self-disinfecting surfaces and infection control. Colloids Surf B Biointerfaces 178:8-21. https://doi.org/10.1016/j.colsurfb. 2019.02.009

Rahimi H, Salehiabar M, Barsbay M, Ghaffarlou M, Kavetskyy T, Sharafi A et al (2021) CRISPR systems for COVID-19 diagnosis. ACS Sensors 6(4):1430-1445. https://doi.org/10.1021/acsse nsors.0c02312

Rauch JN, Valois E, Solley SC, Braig F, Lach RS, Audouard M et al (2021) A scalable, easy-to-deploy protocol for Cas13-based detection of SARS-CoV-2 genetic material. J Clin Microbiol 59(4):e02402-e2420. https://doi.org/10.1128/JCM.02402-20

van Regenmortel MH., Fauquet CM., Bishop DH., Carstens E., Estes M., Lemon S. (2000). Virus taxonomy: classification and nomenclature of viruses. Seventh report of the International Committee on Taxonomy of Viruses. Academic Press San Diego USA.

Report 21. (2020). Estimating COVID-19 cases and reproduction number in Brazil. Imperial College COVID-19 Response Team. Available in: https://www.imperial.ac.uk/mrc-global-infectiousdisease-analysis/covid-19/report-21-brazil/. (Accessed 22 Oct 2021)

Rimoldi SG, Stefani F, Gigantiello A, Polesello S, Comandatore F, Mileto D et al (2020) Presence and vitality of SARS-CoV-2 virus in wastewaters and rivers. Scie Total Environ 744:140911. https://doi.org/10.1016/j.scitotenv.2020.140911

Rokni M, Ghasemi V, Tavakoli Z (2020) Immune responses and pathogenesis of SARS-CoV-2 during an outbreak in Iran: comparison with SARS and MERS. Rev Med Virol 30(3):e2107. https://doi. org/10.1002/rmv.2107

Sallard E., Halloy J., Casane D., Decroly E., van Helden J. (2021). Tracing the origins of SARS-COV-2 in coronavirus phylogenies: a review. Environmental chemistry letters, 1-17. Advance online publication. https://doi.org/10.1007/s10311-020-01151-1

Sanders DW, Jumper CC, Ackerman PJ, Bracha D, Donlic A, Kim H et al (2021) SARS-CoV-2 requires cholesterol for viral entry and pathological syncytia formation. ELife 10:e65962. https://doi. org/10.7554/eLife.65962

Seidah NG, Prat A (2012) The biology and therapeutic targeting of the proprotein convertases. Nat Rev Drug Discovery 11(5):367-383. https://doi.org/10.1038/nrd3699

Seo G, Lee G, Kim MJ, Baek SH, Choi M, Ku KB et al (2020) Rapid detection of COVID-19 causative virus (SARS-CoV-2) in human nasopharyngeal swab specimens using field-effect transistorbased biosensor. ACS Nano 14(4):5135-5142. https://doi.org/ 10.1021/acsnano.0c02823

Shereen MA, Khan S, Kazmi A, Bashir N, Siddique R (2020) COVID19 infection: origin, transmission, and characteristics of human coronaviruses. J Adv Res 24:91-98. https://doi.org/10.1016/j. jare.2020.03.005

Shin MD, Shukla S, Chung YH, Beiss V, Chan SK, Ortega-Rivera OA et al (2020) COVID-19 vaccine development and a potential nanomaterial path forward. Nat Nanotechnol 15:646-655. https:// doi.org/10.1038/s41565-020-0737-y

Silva, F., Erdogmus, E., Shokr, A., Kandula, H., Thirumalaraju, P., Kanakasabapathy, M. K., et al. (2021). SARS-CoV-2 RNA detection by a cellphone-based amplification-free system with CRISPR/CAS-dependent enzymatic (CASCADE) assay. Advanced materials technologies, 2100602. Advance online publication. https://doi.org/10.1002/admt.202100602.

Singh L, Kruger HG, Maguire G, Govender T, Parboosing R (2017) The role of nanotechnology in the treatment of viral infections. Ther Advance Infect Dis 4(4):105-131. https://doi.org/10.1177/ 2049936117713593

Sohrabi C, Alsafi Z, O’Neill N, Khan M, Kerwan A, Al-Jabir A, Iosifidis C, Agha R (2020) World Health Organization declares global emergency: a review of the 2019 novel coronavirus
(COVID-19). Int J Surg (london, England) 76:71-76. https:// doi.org/10.1016/j.ijsu.2020.02.034

Song Z, Xu Y, Bao L, Zhang L, Yu P, Qu Y, Zhu H et al (2019) From SARS to MERS, thrusting coronaviruses into the spotlight. Viruses 11(1):59. https://doi.org/10.3390/v11010059

Spagnol C, Fragal EH, Pereira AGB, Nakamura CV, Muniz EC, Follmann HDM et al (2018) Cellulose nanowhiskers decorated with silver nanoparticles as an additive to antibacterial polymers membranes fabricated by electrospinning. J Colloid Interface Sci 531:705-715. https://doi.org/10.1016/j.jcis.2018.07.096

Srivastava M, Srivastava N, Mishra PK, Malhotra BD (2021) Prospects of nanomaterials-enabled biosensors for COVID-19 detection. Sci Total Environ 754:142363. https://doi.org/10.1016/j.scito tenv.2020.142363

StatNano. Coronavirus: nanotech surface sanitizes Milan with nanomaterials remaining self-sterilized for years I STATNANO. (2020a). https://statnano.com//news/67531/Coronavirus-Nanotech-Surfa ce-Sanitizes-Milan-with-Nanomaterials-Remaining-Self-steri lized-for-Years. (Accessed 22 Oct 2021).

StatNano. Mineral nanocrystal-based coating activated by light kills coronavirus I STATNANO. (2020b). https://statnano.com/news/ 67583/Mineral-Nanocrystal-based-Coating-Activated-by-LightKills-Coronavirus. (Accessed 22 Oct 2021).

Staub, C. (2020). Coronavirus pandemic disrupts recycling sector. https://resource-recycling.com/recycling/2020/03/17/coron avirus-pandemic-disrupts-recycling-sector/. (Accessed 22 Oct 2021).

Su Z, Wu Y (2020) A multiscale and comparative model for receptor binding of 2019 novel coronavirus and the implication of its life cycle in host cells. BioRxiv : the preprint server for biology 02(20):958272. https://doi.org/10.1101/2020.02.20.958272

Talebian S, Wallace GG, Schroeder A, Stellacci F, Conde J (2020) Nanotechnology-based disinfectants and sensors for SARSCoV-2. Nat Nanotechnol 15(8):618-621. https://doi.org/10.1038/ s41565-020-0751-0

Tang Q, Song Y, Shi M, Cheng Y, Zhang W, Xia XQ (2015) Inferring the hosts of coronavirus using dual statistical models based on nucleotide composition. Sci Rep 5:17155. https://doi.org/10. 1038/srep 17155

Tebyetekerwa M, Xu Z, Yang S, Ramakrishna S (2020) Electrospun nanofibers-based face masks. Adv Fiber Mater 2:161-166. https://doi.org/10.1007/s42765-020-00049-5

Tegally H, Wilkinson E, Giovanetti M, Iranzadeh A, Fonseca V, Giandhari J, Doolabh D et al (2020) Emergence and rapid spread of a new severe acute respiratory syndrome-related coronavirus 2 (SARS-CoV-2) lineage with multiple spike mutations in South Africa. MedRxiv 12(21):20248640. https://doi.org/10.1101/ 2020.12.21.20248640

Thorburn F, Bennett S, Modha S, Murdoch D, Gunson R, Murcia PR (2015) The use of next generation sequencing in the diagnosis and typing of respiratory infections. J Clin Virol : Off Publ Pan Am Soc Clin Virol 69:96-100. https://doi.org/10.1016/j.jcv. 2015.06.082

Tian X, Li C, Huang A, Xia S, Lu S, Shi Z, Lu L et al (2020) Potent binding of 2019 novel coronavirus spike protein by a SARS coronavirus-specific human monoclonal antibody. Emerg Microbes Infect 9(1):382-385. https://doi.org/10.1080/22221751.2020. 1729069

To KK, Tsang OT, Leung WS, Tam AR, Wu TC, Lung DC et al (2020) Temporal profiles of viral load in posterior oropharyngeal saliva samples and serum antibody responses during infection by SARS-CoV-2: an observational cohort study. Lancet Infect Dis 20(5):565-574. https://doi.org/10.1016/S1473-3099(20)30196-1

Tob ias A, Carnerero C, Reche C, Massagué J, Via M, Minguilíon $\mathrm{MC}$ et al (2020) Changes in air quality during the lockdown in Barcelona (Spain) one month into the SARSCoV-2 epidemic. 
Sci Total Environ 726:138540. https://doi.org/10.1016/j.scito tenv.2020.138540

Torrente-Rodríguez RM, Lukas H, Tu J, Min J, Yang Y, Xu C et al (2020) SARS-CoV-2 RapidPlex: a graphene-based multiplexed telemedicine platform for rapid and low-cost COVID-19 diagnosis and monitoring. Matter 3(6):1981-1998. https://doi.org/10. 1016/j.matt.2020.09.027

Tosepu R, Gunawan J, Effendy SD, Ahmad AI, Lestari H, Bahar H, Asfian P (2020) Correlation between weather and Covid-19 pandemic in Jakarta. Indonesia Sci Total Environ 42:624. https://doi. org/10.1016/j.scitotenv.2020.138436

Travaglio M, Yu Y, Popovic R, Selley L, Leal NS, Martins LM (2021) Links between air pollution and COVID19 in England. Environ poll (Barking, Essex: 1987) 268(Pt A):115859. https://doi.org/ 10.1016/j.envpol.2020.115859

Vavougios GD (2020) Host proteases as determinants of coronaviral neurotropism and virulence. Brain Behav Immun 87:27. https:// doi.org/10.1016/j.bbi.2020.04.010

Vaze N, Pyrgiotakis G, McDevitt J, Mena L, Melo A, Bedugnis A et al (2019) Inactivation of common hospital acquired pathogens on surfaces and in air utilizing engineered water nanostructures (EWNS) based nano-sanitizers. Nanomed Nanotechnol Biol Med 18:234-242. https://doi.org/10.1016/j.nano.2019.03.003

Vijayan V, Mohapatra A, Uthaman S, Park IK (2019) Recent advances in nanovaccines using biomimetic immunomodulatory materials. Pharm 11(10):534. https://doi.org/10.3390/pharmaceutics11 100534

Wan Y, Shang J, Graham R, Baric RS, Li F (2020) Receptor recognition by the novel coronavirus from Wuhan: an analysis based on decade-long structural studies of SARS coronavirus. J Virol 94(7):e00127-e220. https://doi.org/10.1128/JVI.00127-20

Wang J, Feng H, Zhang S, Ni Z, Ni L, Chen Y et al (2020) SARSCoV-2 RNA detection of hospital isolation wards hygiene monitoring during the Coronavirus Disease 2019 outbreak in a Chinese hospital. Int J Infect Dis. https://doi.org/10.1016/j.ijid. 2020.04.024

Wang Y, Kang H, Liu X, Tong Z (2020) Combination of RT-qPCR testing and clinical features for diagnosis of COVID-19 facilitates management of SARS-CoV-2 outbreak. J Med Virol 92(6):538539. https://doi.org/10.1002/jmv.25721

Wang X, Zhong M, Liu Y, Ma P, Dang L, Meng Q et al (2020) Rapid and sensitive detection of COVID-19 using CRISPR/Cas12abased detection with naked eye readout, CRISPR/Cas12a-NER. Sci Bullet 65(17):1436-1439. https://doi.org/10.1016/j.scib. 2020.04.041

Weiskopf D, Schmitz KS, Raadsen MP, Grifoni A, Okba N, Endeman $\mathrm{H}$ et al (2020) Phenotype and kinetics of SARS-CoV-2-specific $\mathrm{T}$ cells in COVID-19 patients with acute respiratory distress syndrome. Sci Immunol 5(48):eabd2071. https://doi.org/10.1126/ sciimmunol.abd2071

Wender PA, Mitchell DJ, Pattabiraman K, Pelkey ET, Steinman L, Rothbard JB (2000) The design, synthesis, and evaluation of molecules that enable or enhance cellular uptake: peptoid molecular transporters. Proc Natl Acad Sci USA 97(24):13003-13008. https://doi.org/10.1073/pnas.97.24.13003

West AP Jr, Barnes CO, Yang Z, Bjorkman PJ (2021) SARS-CoV-2 lineage B 1526 emerging in the New York region detected by software utility created to query the spike mutational landscape. BioRxiv 02(14):431043. https://doi.org/10.1101/2021.02.14. 431043

WHO (2016). https://www.who.int/health-topics/air-pollution\#tab= tab_1 (Accessed 22 Oct 2021).

WHO (2019) Middle East Respiratory Syndrome Coronavirus (MERSCoV) https://applications.emro.who.int/docs/EMROPub-MERSSEP-2019-EN.pdf?ua=1\&ua=1. Accessed 8 Aug 2021
WHO (2020). Coronavirus disease (COVID-19) technical guidance: laboratory testing for 2019-nCoV in humans, Interim guidance. https://www.who.int/publications/i/item/10665-331501 (Accessed 22 Oct. 2021).

WHO (2020). Origin of SARS-CoV-2, 26 March 2020. World Health Organization. https://apps.who.int/iris/handle/10665/332197 (Accessed 8th Aug 2021).

WHO newsroom (2021). https://www.who.int/news-room/featu re-stories/detail/the-race-for-a-covid-19-vaccine-explained. (Accessed 8th Aug 2021).

WHO guidance document, (2021) . https://extranet.who.int/pqweb/ sites/default/files/documents/Status_COVID_VAX_16Feb 2021.pdf (Accessed 8th Aug 2021)

Wilder-Smith A, Freedman DO (2020) Isolation, quarantine, social distancing and community containment: pivotal role for oldstyle public health measures in the novel coronavirus (2019nCoV) outbreak. J Travel Med. https://doi.org/10.1093/jtm/ taaa020

Wise J (2020) Covid-19: new coronavirus variant is identified in UK. BMJ (clinical Research Ed) 371:m4857. https://doi.org/10.1136/ bmj.m4857

Wrapp D, Wang N, Corbett KS, Goldsmith JA, Hsieh CL, Abiona $\mathrm{O}$ et al (2020) Cryo-EM structure of the 2019-nCoV spike in the prefusion conformation. Sci (New York NY) 367(6483):1260-1263

Wu A, Peng Y, Huang B, Ding X, Wang X, Niu P et al (2020a) Genome composition and divergence of the novel coronavirus (2019$\mathrm{nCoV}$ ) originating in China. Cell Host Microbe 27(3):325-328. https://doi.org/10.1016/j.chom.2020.02.001

Wu F, Zhao S, Yu B, Chen YM, Wang W, Song ZG et al (2020b) A new coronavirus associated with human respiratory disease in China. Nature 579(7798):265-269. https://doi.org/10.1038/ s41586-020-2008-3

Wu X, Nethery RC, Sabath B, Braun D, Dominici F (2020c) Exposure to air pollution and COVID-19 mortality in the United States. MedRxiv. https://doi.org/10.1101/2020.04.05.20054502

Wurtzer S, Marechal V, Mouchel JM, Moulin L (2020) Time course quantitative detection of SARS-CoV-2 in Parisian wastewaters correlates with COVID-19 con-firmed cases. MedRxiv. https:// doi.org/10.1101/2020.04.12.20062679

Xiang J, Yan M, Li H, Liu T, Lin C, Huang S, Chen S (2020) Evaluation of enzyme-linked immunoassay and colloidal gold-immunochromatographic assay kit for detection of novel coronavirus (SARS-Cov-2) causing an outbreak of pneumonia (COVID-19). MedRxiv 02:27-20028787. https://doi.org/10.1101/2020.02.27. 20028787

Yao TT, Qian JD, Zhu WY, Wang Y, Wang GQ (2020) A systematic review of lopinavir therapy for SARS coronavirus and MERS coronavirus-a possible reference for coronavirus disease-19 treatment option. J Med Virol 92(6):556-563. https://doi.org/ 10.1002/jmv. 25729

Yao X, Ye F, Zhang M, Cui C, Huang B, Niu P et al (2020) In vitro antiviral activity and projection of optimized dosing design of hydroxychloroquine for the treatment of severe acute respiratory syndrome coronavirus 2 (SARS-CoV-2). Clin Infect Dis : Off Publ Infect Dis Soc Am 71(15):732-739. https://doi.org/10. 1093/cid/ciaa237

Ye M, Fu D, Ren Y, Wang F, Wang D, Zhang F, Xia X, Lv T (2020) Treatment with convalescent plasma for COVID-19 patients in Wuhan. China J Med Virol 92(10):1890-1901. https://doi.org/ 10.1002/jmv. 25882

Yetisen AK, Qu H, Manbachi A, Butt H, Dokmeci MR, Hinestroza JP et al (2016) Nanotechnology in textiles. ACS Nano 10:30423068. https://doi.org/10.1021/acsnano.5b08176 
Yin Y, Wunderink RG (2018) MERS, SARS and other coronaviruses as causes of pneumonia. Respirology (Carlton Vic) 23(2):130-137. https://doi.org/10.1111/resp.13196

Yuen CK, Lam JY, Wong WM, Mak LF, Wang X, Chu H et al (2020) SARS-CoV-2 nsp13, nsp14, nsp15 and orf6 function as potent interferon antagonists. Emerg Microbes Infect 9(1):1418-1428. https://doi.org/10.1080/22221751.2020.1780953

Zaki AM, van Boheemen S, Bestebroer TM, Osterhaus AD, Fouchier RA (2012) Isolation of a novel coronavirus from a man with pneumonia in Saudi Arabia. N Engl J Med 367(19):1814-1820. https://doi.org/10.1056/NEJMoa1211721

Zambrano-Monserrate MA, Ruano MA, Sanchez-Alcalde L (2020) Indirect effects of COVID-19 on the environment. Sci Total Environ 728:138813. https://doi.org/10.1016/j.scitotenv.2020. 138813

Zhang L, Lin D, Sun X, Rox K, Hilgenfeld R (2020) X-ray structure of main protease of the novel coronavirus SARS-CoV-2 enables design of $\alpha$-ketoamide inhibitors. BioRxiv. https://doi.org/10. $1101 / 2020.02 .17 .952879$

Zhang F., Abudayyeh O. O., Gootenberg J. S. (2020). A protocol for detection of COVID-19 using CRISPR diagnostics; Broad Institute, 8. https://broad.io/sherlockprotocol.

Zhao Y, Chen F, Li Q, Wang L, Fan C (2015) Isothermal amplification of nucleic acids. Chem Rev 115(22):12491-12545. https://doi. org/10.1021/acs.chemrev.5b00428
Zhao J, Yuan Q, Wang H, Liu W, Liao X, Su Y et al (2020) Antibody responses to SARS-CoV-2 in patients with novel coronavirus disease 2019. Clin Infect Dis: Off Publ Infect Dis Soc Am 71(16):2027-2034. https://doi.org/10.1093/cid/ciaa344

Zhao Z, Cui H, Song W, Ru X, Zhou W, Yu X (2020) A simple magnetic nanoparticle based viral RNA extraction method for efficient detection of SARS-CoV-2. BioRxiv. https://doi.org/10. $1101 / 2020.02 .22 .961268$

Zhong NS, Zheng BJ, Li YM, Poon, Xie ZH, Chan KH, Li PH et al (2003) Epidemiology and cause of severe acute respiratory syndrome (SARS) in Guangdong People's Republic of China in February 2003. Lancet (London, England) 362(9393):1353-1358. https://doi.org/10.1016/s0140-6736(03)14630-2

Zhou P, Yang XL, Wang XG, Hu B, Zhang L, Zhang W et al (2020) Addendum: A pneumonia outbreak associated with a new coronavirus of probable bat origin. Nature 588(7836):E6. https://doi. org/10.1038/s41586-020-2951-z

Publisher's note Springer Nature remains neutral with regard to jurisdictional claims in published maps and institutional affiliations. 